
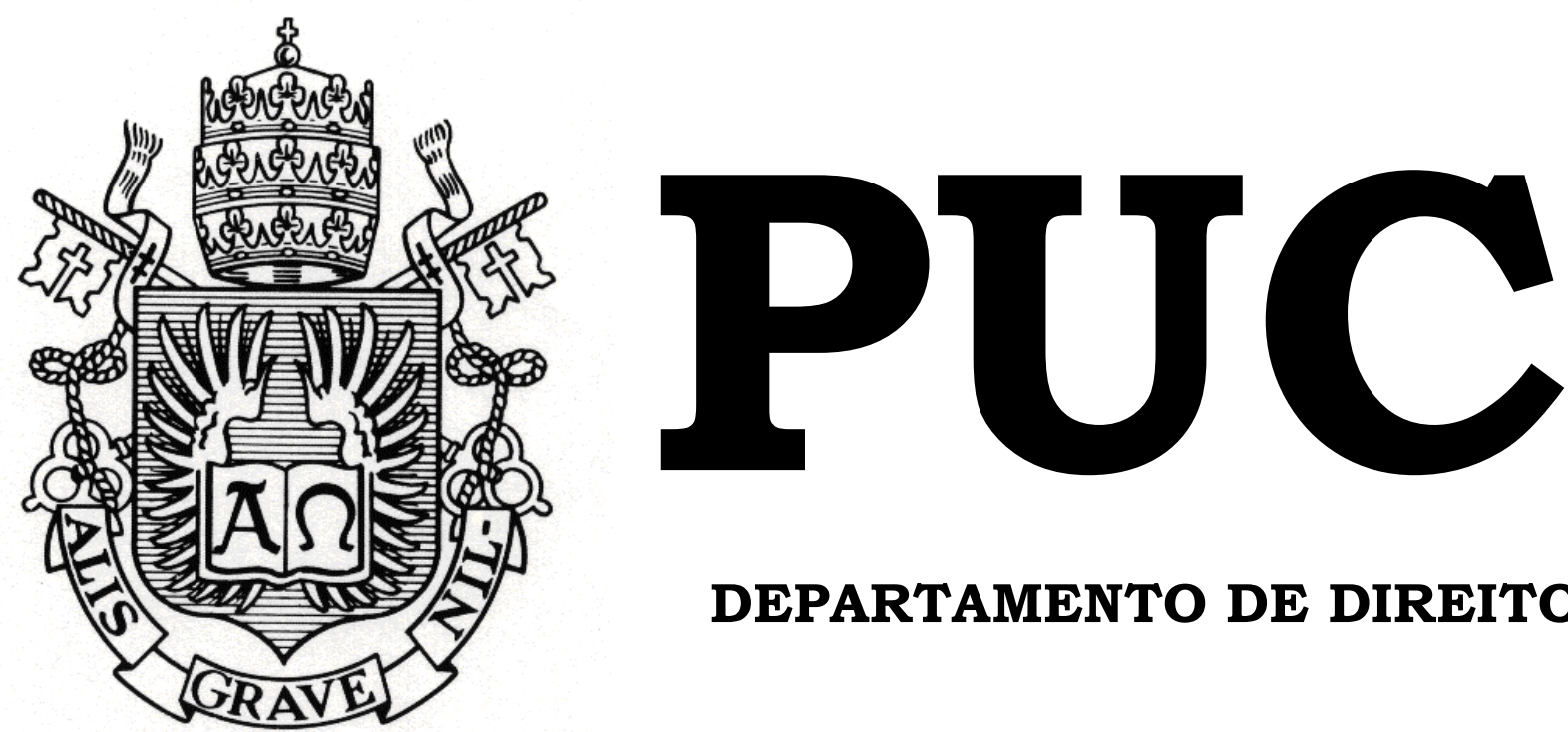

DEPARTAMENTO DE DIREITO

\title{
Garantias Constitucionais do Réu em Processos Midiáticos
}

$$
\text { por }
$$

Rafaela Cordeiro Bazani

ORIENTADOR: Thiago Ragonha Varela

2018.2

PONTIFÍCIA UNIVERSIDADE CATÓLICA DO RIO DE JANEIRO

RUA MARQUÊS DE SÃO VICENTE, 225 - CEP 22453-900

$$
\text { RIO DE JANEIRO - BRASIL }
$$




\title{
Garantias Constitucionais do Réu em Processos Midiáticos
}

\author{
por
}

Rafaela Cordeiro Bazani

Monografia apresentada ao

Departamento de Direito da Pontifícia Universidade Católica do Rio de Janeiro (PUC-Rio) para a obtenção do Título de Bacharel em Direito.

Orientador: Thiago Ragonha Varela

2018.2 


\section{Agradecimentos}

Esse trabalho não poderia se iniciar de outro modo, que não pelo agradecimento à minha mãe, Maria Aparecida Bazani, maior heroína da minha vida, meu Norte e espelho, exemplo de mulher e de profissional. Obrigada por sempre acreditar no meu melhor e por sempre me dar a mão, mas principalmente, obrigada por acreditar absolutamente em meu sucesso, não existem palavras capazes de te descrever.

À Luiz Antônio Carvalho, meu pai do coração, exemplo intelectual e de profissional impecável, obrigada por todo amor e carinho dedicado a mim e à nossa família.

À minha irmã, Mikayla Cordeiro Bazani, fruto de minha imensurável admiração, imagem de fortaleza, por todo o carinho e dedicação que dirigiu a mim, obrigada por me fazer ir além, a não me contentar com sonhos pequenos e me mostrar o caminho para alcançá-los.

Ao meu pai, Pedro Cordeiro, minha avó, Elza Bazani e minha prima, Nádia Cordeiro, que já não mais estão aqui, por terem projetado seus sonhos em mim, e me inspirado a conquista-los, obrigada por todo amor e por sempre olharem por mim.

Às minhas colegas de faculdade, Kianne Barion, Flavia Ferreira, Milena Sepulveda, Camile Tchmola, e Maria Victória Avelino, pela incrível trajetória na PUC-Rio, por compartilhar os sonhos e as tristezas, obrigada pelo lindo trajeto, a vocês todo meu amor e gratidão.

Às minhas amigas Isadora Kerti, Taciana Maia e Luíza Maciel, minhas inspirações diárias, toda a gratidão por terem me acolhido, por serem minha base e meu carinho, obrigada por serem a família que escolhi, vocês são minha rocha.

À Luana Fontes e Laysa Fontes, inspirações acadêmicas, por me impulsionarem cada vez mais a frente, obrigada por me fazer acreditar, palavras não bastam para agradecer toda a gratidão que tenho por vocês.

Por fim, agradeço ao meu orientador, Thiago Ragonha Varela, pela troca de experiência, pela dedicação e atenção. 


\section{Resumo}

A presente monografia pretende a realização de uma análise a respeito dos julgamentos com grande repercussão no cenário político-jurídico atual. Para tanto, objetiva versar sobre as máculas jurídicas, no tocante das garantias processuais de que se valem os réus, em contraponto com a exacerbada divulgação midiática de tais processos, esses, que já se valem de idiossincrasias específicas por constituírem alvo de interesse público. Nesse sentido, pretende-se entender esse fenômeno, relativamente recente, nos quais as garantias constitucionais absolutas e fundamentais, encontram-se taxadas pela subsidiariedade mediante a veiculação de informação processual sem o devido acautelamento, acarretando na interferência no devido processo legal e na presunção de inocência, que deveriam revestir os réus. Para tanto, examinaremos os princípios constitucionais que regem o processo judicial, bem como os limites do alcance midiático e do benefício pró societatis que a publicização dessas informações acarretam. Assim sendo, passaremos à averiguação de alguns casos emblemáticos, marcados pela sua repercussão, para que se possa entender as consequências de tal interferência.

\section{Palavras Chave}

Garantias Processuais - Direitos Fundamentais - Mídia - Devido Processo Legal - Interesse Público - Princípios Constitucionais. 


\section{Sumário}

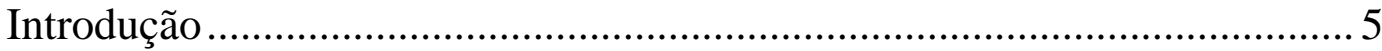

Capítulo 1. Direitos Fundamentais e Garantias Constitucionais ..................... 7

1.1. A tutela máxima dos direitos fundamentais e sua elevação ao texto

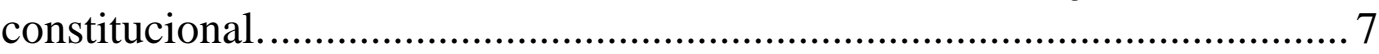

1.2. Imperatividade de segurança jurídica e o juízo imparcial..................... 13

1.3. Princípios constitucionais no processo legal brasileiro e os tratados

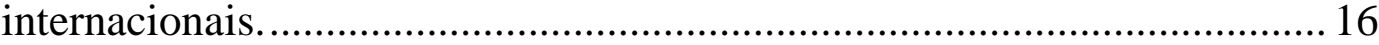

CAPÍTULO 2. Princípio Da Publicidade e Da Transparência....................... 26

2.1. Limitação da imprensa: Ther trial by the mídia e o ideal

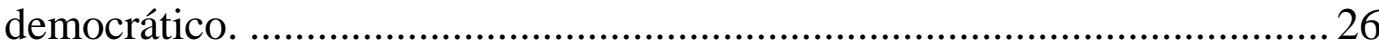

2.2. Pertinência Político-social da divulgação de informações

processuais e a ponderação de princípios......................................................... 32

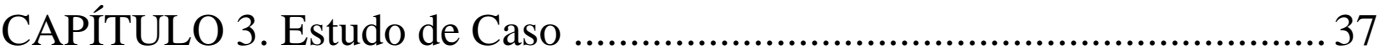

3.1. Luiz Inácio Lula da Silva e a Operação Lava-Jato................................ 37

3.2. Inquérito Policial - Escola Base ........................................................... 45

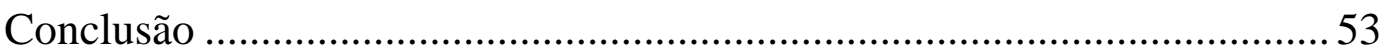

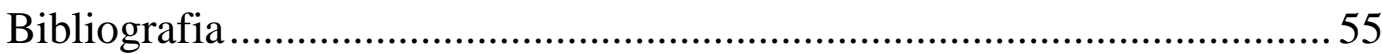




\section{Introdução}

O direito por excelência consubstancia-se pelo seu caractere mutacional. É inerente à essa ciência tal adjetivo, uma vez que, por definição, o direito não inova, segue o fluxo ditado pela sociedade que o reflete e que se recicla e modifica constantemente. Nos últimos 30 anos, contudo, tal processo teve seu efeito catabolizado, na medida em que a redemocratização e o avanço social exponencial, desencadeados pelas tecnologias, provocaram maior movimentos e desdobramentos sociais, logo, imputando em um avanço em disciplinar novos aspectos da mesma.

A informação, portanto, nunca foi tão vasta, farta e acessível para a sociedade, tornando tal ciência jurídica, entendível e demandada como nunca antes. Com efeito, a atualidade do direito processual-constitucional no Brasil encontra-se sob holofotes midiáticos inquisitoriais, espaço no qual conceitos como a mutação constitucional e as garantias constitucionais ganham novos significados e projeções.

O impacto da vivência de tal momento, posto isto, não torna estranho a discussão do direito como meio para saciar os anseios sociais. É em tal preceituação que a presente monografia se alicerça, possuindo como base a ponderação das garantias fundamentais postas diariamente em xeque, bem como os princípios que regem o devido processo legal, em detrimento da ação jurídica com intuito político.

O que se visa analisar é se tal mudança encontra resguardo dentro da evolução do direito, como mais um instrumento de sua mutação e evolução, ou se enfrentamos uma crise das garantias constitucionais-processuais contrastada em relação à ampla divulgação midiática de informações processuais, que não se observa no devido processo legal.

Posto isso, estudaremos no Capitulo Um a evolução dos direitos elevados ao texto constitucional, bem como a evolução de sua tutela ao longo das Cartas de Direito Constitucionais, e a maneira com que esses estabelecem 
as garantias de aspectos imprescindíveis para o ordenamento jurídico, como a segurança jurídica.

Traçaremos também, a análise dos princípios que regem o devido processo legal, sob a ótica de sua prerrogativa para a garantia de um Estado Democrático de Direitos, sob a égide da efetivação dos direitos fundamentais.

A seu turno, o Capítulo dois traçará a natureza as prerrogativas elencadas no artigo quinto da Constituição de 1988 e sua função imperativa para o sustento do direito no que tange o ideal de justiça. Para tanto, será destrinchada as ameaças representadas à essa esfera protetiva, por elementos como o Tryal by the mídia, a proliferação de informações arbitrárias e rasas, e a irresponsabilidade das agências de informação.

À pretexto de demonstrar como essa relativização ocorre no caso concreto, o Capítulo três sustenta-se no estudo da matéria processual e jornalística constante de dois processos. No primeiro, traça-se os contornos do processo que julgou e condenou o ex presidente Luiz Inácio Lula da Silva, abordando os aspectos específicos de tal processo, tais como a rés pública $\mathrm{e}$ a representatividade de sua posição política.

O segundo caso, abordará uma das maiores injustiças cometida pelo jornalismo brasileiro, a cobertura do inquérito policial referente à notícia crime que imputou crimes de pedofilia e pornografia infantil, aos donos da Escola Base, situada em São Paulo. O caso em voga, é despido dos contornos políticos que pelos quais o processo de Lula se caracteriza, possibilitando uma compreensão mais abrangente da relativização de direitos a que se analisa.

São esses os temas abordados na presente monografia, que se propõe a análise do julgamento deslegitimado efetuado por entidades não jurídicas. 


\section{Capítulo 1. Direitos Fundamentais e Garantias Constitucionais}

\subsection{A tutela máxima dos direitos fundamentais e sua elevação ao texto constitucional.}

A construção histórica de um código que regesse o dever/ser e regras de interação se deu a partir do momento em que o homem inicia a convivência em sociedade. Dessa maneira, é possível determinar, mesmo nas sociedades mais ancestrais, a existência de regras de conduta pelas quais tais indivíduos se governavam.

Nessa seara, os códigos de conduta passaram a ser um meio de construção de atribuições, resguardes e, por meio da imposição de limites para o convívio social, uma figura de conservação e de proteção das interações humanas, que acompanha a trajetória histórica do homem como sociedade, sem o qual, não poderia ter se sofisticado à amplitude apresentada na atualidade.

É assim que se percebe que, com processo de cartulação de determinados mandamentos, na forma de regra de conduta, cria-se uma figura de resguarde e de proteção das interações humanas, que acompanha a trajetória histórica do homem como sociedade, em sua complexidade atual, salvaguardando e concedendo atenção especial à certos caracteres em sua esfera de proteção.

Diante dessa prerrogativa, passa-se ao entendimento de que existem direitos que são pretéritos a qualquer ordenamento. São soberanos, na medida em que não se pautam por tal prerrogativa de cartulação, sendo originários da própria natureza humana em si. São oriundos dos costumes, moldados pela maneira com que o homem interage em seu meio social, atuando como um senso justo, sendo instrumento da própria construção do convívio em si. O que se faz referência aqui, são os chamados direitos naturais do homem, aqueles inerentes à sua condição humana, sem que haja a necessidade de um ente garantidor e afirmador desses. 
Pontua com abrangência o Professor Paulo Nader a respeito da natureza de tal direito:

"Há uma outra ordem, superior àquela e que é a expressão do Direito justo. É a ideia de Direito perfeito e por isso deve servir de modelo para o legislador. É o Direito ideal, mas ideal não no sentido utópico, mas um ideal alcançável. A divergência maior na conceituação do Direito Natural está centralizada na origem e fundamentação desse Direito. Para o estoicismo helênico, localizava-se na natureza cósmica. No pensamento teológico medieval. O direito Natural seria a expressão da vontade divina. Para outros, se fundamenta apenas na razão. O pensamento predominantemente na atualidade é o de que o Direito Natural se fundamenta na natureza humana". ${ }^{1}$

O que se percebe, é que a existência de tal esfera de tutela, faz-se tão cara ao homem, e caminha juntamente à sua construção histórica, que sua prerrogativa se torna inquestionável, e sua garantia de indispensável importância. Diz-se isso, uma vez que o direito natural se traduz como o pilar das garantias que hoje habitam as cartas de direitos constitucionais que regem o direito contemporâneo.

É assim, que é importante trazer à tona o jusnaturalismo, uma das principais correntes filosóficas que alicerça o direito ${ }^{2}$. Tal dogmática nos ensina que há uma classe de direitos, determinada como direito natural que precedem o surgimento do Estado como entidade, não se vinculando, ou se relacionando com o direito positivo sob um vínculo de dependência.

$\mathrm{O}$ que se quer dizer com isso, é que tal grupo de garantias, que independem da vontade constituinte e legislativa, existem por si só, sendo considerados primos, ante a qualquer outra relação jurídica. Tal definição é bem exemplificada nas palavras de Paulo Nader, como sendo um direito que "não é escrito, não é criado pela sociedade, nem é formulado pelo Estado"3.

Essa relação, que resguarda a primariedade da tutela do homem, por si só já denota a importância de sua proteção, haja visto que elimina do arbítrio constituinte e positivado, e, por conseguinte legislativo, a que se

\footnotetext{
${ }^{1}$ NADER, Paulo. Introdução ao Estudo do Direito. $23^{\mathrm{a}}$ Ed. Rio de Janeiro: Forense, 2003 p. 366.

${ }^{2}$ BARROSO, Luís Roberto. Curso de Direito Constitucional Contemporâneo. Editora Saraiva. p. 281.

${ }^{33}$ NADER, Paulo. Op.cit., p.34.
} 
vincula o fluxo histórico e todas suas instabilidades, a responsabilidade de institucionalização dos direitos e garantias fundamentais.

A importância, ao entender sobre tais tutelas, é que se fala aqui de prerrogativas bases a que se derivam toda a esfera de proteção do homem, são pilares e basilares à construção social, como o direito à vida, à liberdade e à dignidade.

Tais tutelas, tornaram-se os embriões dos direitos tidos como fundamentais, que a princípio, são absolutos, independentemente de qualquer fluxo histórico ou ordenamento jurídico específico, uma vez que também são revestidos de proteção pelo direito internacional.

Ao analisarmos a história recente, é importante destacar a carta de direitos do homem e do cidadão, assinada e ratificada no ano de $1948^{4}$, uma vez que de crucial importância, nesse sentido, por conceber a prerrogativa de universalizar a proteção dos direitos do homem, sedimentando o caminho para que cartas constitucionais vindouras também os incorporassem em seu texto. ${ }^{5}$

O ideal constitucional, consagrado pela Constituição de 1988, não é, se não, resultado de um fluxo histórico cominativo, que possibilitou a compreensão da importância da elevação dos direitos fundamentais ao resguarde do texto máximo do ordenamento. Dessa forma, o caminho de afirmação desses direitos mostrou-se longo, até a compreensão de que seria necessário a proteção de tais, por meio da magna carta.

Ao analisarmos as constituições promulgadas no Brasil, pode-se avaliar que a tutela de direitos tidos como fundamentais sempre esteve presente em certo grau. Contudo, aponta-se que, em alguns textos, foi dada maior importância à determinadas tutelas, variando a inclusão de certos direitos nos róis elencados em cada texto constitucional no decorrer histórico.

A Constituição do império, primeira constituição do Brasil, por exemplo, promulgada em 1824, foi uma das primeiras cartas constitucionais

\footnotetext{
${ }^{4}$ Declaração Universal dos direitos do homem e do cidadão

${ }^{5}$ MENDES, Gilmar Ferreira e BRANCO, Paulo Gustavo Gonet. Curso de direito Constitucional. Editora Saraiva. p.156.
} 
a prever um rol de salvaguardas que podem ser encampadas como direitos fundamentais. ${ }^{6}$ Determinava, dessa forma, pelo lecionado em seu artigo 179, a "A inviolabilidade dos Direitos Civis, e Políticos dos Cidadãos Brazileiros [sic], que tem por base a liberdade, a segurança individual, e a propriedade, é garantida pela Constituição do Império", que em seu inciso IV já estabelecia a liberdade de expressão sem dependência de censura, mediante a responsabilidade de seu conteúdo.

É importante pontuar, que em seu inciso XI, a carta de 1824 também garante que a sentença será dada pela autoridade competente, assegurandose que não há crime sem lei anterior que o preveja, reforçando, logo em seu inciso XIII, que a lei é igual para todos, quer castigue, ou recompense.

A seu turno, a primeira Constituição do Brasil República, promulgada em $1891^{7}$, assiste os direitos do homem por meio de seu artigo 72, ampliandoos em relação à sua antecessora. Assim ensina que "A Constituição assegura a brasileiros e a estrangeiros residentes no paiz a inviolabilidade dos direitos concernentes a liberdade, a segurança individual e á propriedade" [sic.].

Deve-se atentar para o que, enquanto na Constituição de 1824, a noção de "igualdade" parte do princípio de que a "Lei é igual para todos" [sic], na carta de 1891 traz a noção de igualdade mais aprofundada, uma vez que determina que "Todos são iguaes perante a lei." [sic], revogando assim todos os privilégios e títulos reconhecidos pela constituição do Império, bem como a pena de morte, excetuando-se a legislação militar em tempos de guerra.

A Carta de $1934^{8}$ segue assim inovando, ao perceber a tutela de ordem econômico-social, que, dos seus artigos 115 a 143, elevou à qualidade de fundamentais os direitos sociais. Mais uma vez, o critério de igualdade perfez-se ampliado, vez que passou a determinar a não distinção baseada em sexo ou raça, bem como elencando como tutela constitucional da mulher o

6 Artigo 179 da Constituição do Império 1824. Disponível em http://www.planalto.gov.br/ccivil 03/constituicao/constituicao24.htm4. Acesso em: 20 out. 2018. ${ }^{7}$ Primeira Constituição da República. Disponível em http://www.planalto.gov.br/ccivil 03/Constituicao/Constituicao91.htm. Acesso em: 20 out. 2018. ${ }^{8}$ Texto da Constituição de 1934. Disponível em: http://www.planalto.gov.br/ccivil_03/Constituicao/Constituicao34.htm. Acesso em: 20 out. 2018. 
direito ao voto, o que, historicamente, apresentou-se inédito no texto constitucional. Tais avanços foram, no entanto, em seguida suprimidos pela constituição que instaurou a ditadura em $1937^{9}$, e que também instituiu a censura prévia.

É nesse sentido, que a constituição de $1946^{10}$ ganha grande importância, ao receber a tarefa de reintroduzir as proteções constitucionais aos direitos e garantias do homem, por meio da redemocratização do país, abolindo a pena de morte, instituindo mais uma vez a liberdade de manifestação de pensamento sem que houvesse o crivo da censura, bem como as tutelas processuais e o devido processo legal, eliminando os tribunais especiais implantados pela carta anterior.

Tal progressão, que seguia a esteira mundial de reforço das garantias constitucionais prezando pelo combate à arbitrariedade diante do contexto histórico do pós segunda-guerra vivido, encontrou óbice na Carta de 1967 ${ }^{11}$, que, apesar de manter tais garantias, barrou o avanço de direitos na medida em que instituiu um regime ditatorial que deu início à um processo de exceção dos mesmos. Dessa forma, na marcha do avanço de um regime ditatorial, os Atos Institucionais implantaram mais uma vez a censura prévia, bem como a inexistência das garantias constitucionais processuais.

Por fim, a intitulada Carta cidadã, concebida em 1988, trouxe o texto de maior relevância no Brasil, até então, para o ordenamento jurídico no que tange os direitos do homem. Tal carta sagrou em seus cinco primeiros artigos o círculo de proteção primária que o Estado resguarda os seus, incluindo uma série de direitos neste rol.

Assim, reforçada a igualdade material, o devido processo legal, bem como a livre manifestação de pensamento e o princípio da transparência e do

\footnotetext{
${ }^{9}$ Texto da Constituição de 1937. Disponível em: http://www.planalto.gov.br/ccivil 03/Constituicao/Constituicao37.htm. Acesso em: 20 out. 2018. ${ }^{10}$ Texto da Constituição de 1946. Disponível em: http://www.planalto.gov.br/ccivil_03/Constituicao/Constituicao46.htm. Acesso em: 20 out. 2018. ${ }^{11}$ Texto da Constituição de 1967. Disponível em: http://www.planalto.gov.br/ccivil_03/Constituicao/Constituicao67.htm. Acesso em: 20 out. 2018.
} 
melhor interesse social, tal texto foi o mais progressista quando se pensa na tutela do homem.

É evidente que a falha institucional na efetivação de tais tutelas é inescusável, o que não pode ofuscar a importância de um texto social, político e econômico do calibre da Magna Carta de 1988.

Por todo o exposto, fica evidente, ao traçar a trilha histórica, da importância dos textos apresentados, e das tutelas conferidas à cada garantia, que se destaque o laço que estes guardem em relação ao momento político vivenciado em cada época destacada. É claro, então, que a mentalidade e política de cada momento histórico, ditou a proteção conferida pelo direito, uma vez que atrelada diretamente ao fluxo histórico à que esse se sujeita.

A prerrogativa apresentada, posto isso, é a tutela histórica e costumeira de tais direitos. Adentra-se, logo, na questão chave que se pretende apresentar, isto é, a tutela da liberdade, escopo principal para as garantias processuais trazidas pelo texto constitucional de 1988.

O direito à liberdade engloba-se no núcleo de direitos fundamentais que são abarcados no texto carta de 1988. Lê-se, então, que detentor que é o Estado do poder de punir, também detém a prerrogativa de garantidor de tais direitos, sem os quais não haveria que se falar em estado democrático. Assim, é que desse embrião, se desdobra os princípios que fazem parte da tutela processual, elencando-se em tal rol a presunção de inocência, a garantia do devido processo legal e a legitimidade de julgar e sentenciar pela autoridade competente.

O que nos traz à ponderação enfrentada pelo direito na atualidade. É visível uma crescente distorção ao direito de manifestação livre de pensamento e o princípio do interesse social, quando contrastado com a efetivação e positivação das garantias processuais, tão relevantes quanto aqueles. Isso porque, não há que se falar em devido processo legal, quando há a instauração de mais um órgão julgador, além daquele revestido de tal legitimidade pelo poder judiciário. 
Fica evidente que quando se fala em direitos fundamentais, mais especificamente nas espécies de liberdade a serem resguardadas sobre as quais se tratam aqui, não se pode afirmar que esses sejam absolutos, uma vez que essa premissa já não é mais adotada na atualidade. Entende-se, posto isso, que tal esfera de direitos pode vir a ser objeto de limitação quando em contraponto com outra tutela de mesma qualidade, não sendo absolutos. ${ }^{12}$

O que se tem apresentado, posto isso, é a criação de uma sociedadejuiz, instituidora de penas e anseios próprios, que extrapolam os atos jurídicos instituídos pelo magistrado, uma vez que a explanação de informações processuais não encontra óbice à título de livre manifestação de vontade e do melhor interesse do povo, chegando a nem se justificar para tanto em determinados casos.

É necessário que se indague, ante todo o exposto, como erigir um estado democrático de direito, em que as decisões judiciais não se façam ordeiras ante à imparcialidade do juiz e o princípio do devido processo legal, uma vez que criado um segundo instituto julgador? Como consolidar o ideal de segurança jurídica?

\subsection{Imperatividade de segurança jurídica e o juízo imparcial.}

É cediço que o ideal da segurança jurídica se perfaz por meio de um elemento simples: a estabilidade. Não há que se falar em um Estado Democrático de Direito, sem que esse seja alicerçado por normas, a que, por sua vez, se baseiam o juízo de decisão no caso concreto.

O que se extrai dessa prerrogativa, é que tal princípio opera como um fio condutor, um ambiente por meio do qual o magistrado pondera sua tomada de decisão, seja ela por vinculação à norma jurídica, seja por apreço ao precedente que encampa o caso concreto.

\footnotetext{
${ }^{12}$ MENDES, Gilmar Ferreira e BRANCO, Paulo Gustavo Gonet. Curso de direito constitucional. Editora Saraiva. p. 143.
} 
É mister que se aponte, posto isso, que o princípio da segurança jurídica vincula a todos os órgãos do poder judiciário, bem como da administração pública, no sentindo de convergirem para a garantia de decisões e atos que não se contradigam, garantindo uma justiça una, coesa, e um direito que se aplique à todos de maneira semelhante, sem a fragilidade que é característica de sistemas instáveis. Assim, se perfaz uma estrutura jurídica, e de leis, forte e garantidora das próprias decisões que emana por meio de seus legitimados.

$\mathrm{O}$ que se tem por isso, é que apenas dessa maneira se edifica um Estado, e por consequência disso, um ordenamento jurídico, que, por meio da solidez de seus mandamentos, é detentor da confiança da sociedade quanto aos atos, decisões e conduta que emana. Do contrário, não haveria que se falar em efetividade do direito.

Antes mesmo de adentrarmos à maiores discussões, devemos determinar o entendimento do Professor José Afonso da Silva, sobre o que se entende a respeito do conceito de segurança originária na esfera do direito, assim aduz que a segurança "[...] exige a positividade do direito e é, neste contexto, que a segurança se entronca com a Constituição, na medida em que esta constitui o fundamento de validade do direito positivo"13.

É este o meio, no qual o conceito de segurança jurídica encontra sua definição. Assim posto, continua a lecionar a respeito dessa definição, seguindo, então, o Professor cravando o conceito de segurança jurídica, segundo o qual, entende como sendo "[...] uma garantia que decorre dessa positividade. Assim é que o direito constitucional positivo, traduzido na Constituição, é que define os contornos da segurança jurídica da cidadania"14

$\mathrm{O}$ que se pretende demonstrar, então, é que por meio de um ordenamento jurídico forte, aqui entendido como um ordenamento reprodutor de normas e decisões que encontram materializações que não se contradigam, por meio da garantia de respeito ao mesmo que os mecanismos

13 SILVA, José Afonso da. Constituição e segurança jurídica, in ROCHA, Carmen Lúcia Antunes. Constituição e segurança jurídica, p. 16.

${ }^{14}$ Ibid. p. 17. 
do direito impõem, cria-se o ideal de um estado forte e garantidor dos seus direitos.

É nesse sentido que adentramos ao ponto principal a ser questionado e desenvolvido nesta presente monografia. Como demonstrado pelo capítulo anterior, existem direitos que ocupam a máxima escala hierárquica apresentada no ordenamento jurídico, direitos estes tidos como fundamentais, vinculados à própria existência do homem e protegidos pelo texto máximo.

Entretanto, é preciso desconstruir o imaginário de que tal grupo de direitos goze de uma presunção de caráter absoluto, e que não podem ser relativizados diante da factualidade. Isso porque estes podem encontrar limitações na medida em que são ponderados, e avaliados, junto a outros da mesma espécie, quando em conflito diante do caso concreto.

$\mathrm{O}$ que se pretende afirmar por meio dessa assertiva, é que o devido processo legal, regido por todas suas garantias constitucionais, vem sendo colocado em xeque diante do exercício inconsequente da liberdade de manifestação, que permite a divulgação, por meios midiáticos, de fatos processuais, o que não necessariamente serve à um propósito jurídico probo.

Tal caráter público que assume o processo a partir da veiculação em mídias, já provou, como veremos na repercussão de estudo do caso concreto abordado pelo capítulo três, podem afetar e mudar o curso do devido processo legal até mesmo anteriormente à instauração do processo em si, isto é, na fase de investigação de autoria e materialidade da existência do fato em si, influenciando na cominação de penas e no juízo decisório do juiz.

O que se observa aqui, é a contraposição de dois direitos que se traduzem pela ramificação do direito à liberdade, tanto sob a interpretação como meio de manifestação de pensamento e de expressão, tanto o direito à liberdade que se qualifica por meio das garantias processuais constantes do artigo $5^{\circ}$ da Constituição, atacando também a própria efetivação do direito processual em si. 
Tal contraposição, contudo, não se vê operada em equilíbrio, mas justamente o contrário, consubstanciando-se em uma situação na qual a execução de um direito acaba por anular o outro, sem que isso sirva à um propósito social específico, que poderia vir a gerar benesses ao interesse público.

A conclusão a que se pretende chegar, é que, quando se pondera a respeito da impossibilidade de assegurar que se perfaça o ideal de segurança jurídica, quando se leva em conta a instabilidade do juízo decisório, uma vez que influenciado por aspectos externos ao direito em si, mina-se a capacidade de se perfazer o ideal constitucional de justiça e segurança.

O que se cria, na verdade, é um ambiente jurídico no qual as decisões do judiciário em processos que recebem a incidência midiática, e, por consequência, as penas determinadas por esse, passam a não levar em conta apenas as fontes legais de direito, isto é, a doutrina, jurisprudência e as normas jurídicas.

Com efeito, passam a extrapolar o ideal legal desses aspectos processuais, vez que a pena passa a ser cominada, não por um juiz, mas pelo juízo social, sem presunção de inocência, nem máximo legal.

Ingressa, posto isso, nessa equação por assim dizer, uma quarta fonte do direito. Tal fonte, no entanto, não parte da premissa de legalidade, e se sujeita a vinculações que não se baseiam em nenhum juízo legal. Alicerça-se assim, apenas pelo no julgamento alheio e arbitrário, sem vedação, previsão legal ou razoabilidade na pena a ser cumprida, sem, sequer, ser aplicada por alguém legitimado para tal prerrogativa.

\subsection{Princípios constitucionais no processo legal brasileiro e os tratados internacionais.}

É necessário que se apresente, diante do que se sustentou até o presente momento, os princípios constitucionais responsáveis pela regência 
do devido processo legal, que são pertinentes à construção da tese aqui apresentada.

Insta salientar, no entanto, que algumas dessas prerrogativas também são fruto da incorporação de tratados internacionais no ordenamento jurídico interno, e indispensáveis de menção no presente texto, tal como o Pacto de São José da Costa Rica, introduzindo, no âmbito das garantias processuais, uma série de direitos indispensáveis ao réu no curso do processo legal.

Posto isso, diante do explanado na Constituição de 1988, o que se extrai é um rol de garantias apresentado pelo artigo $5^{\circ}$ da Carta, encampando inúmeros aspectos do desenvolvimento do processo legal a que se tem por base a Lei 13.105/2015 (Código de Processo Civil) e a Lei 3.689/1941 (Código de Processo Penal), a que se passa a examinar agora.

Em primeira análise, é necessário que se invoque o princípio da presunção de inocência, a que se resguarda toda a parte ré nos processos. Inicia-se pelo estudo de tal princípio, uma vez que esse é o primeiro resguarde que se vale o indivíduo no momento em que se vê como parte no processo, detendo, a acusação, que a depender da espécie de ação pode ser o Estado ou o particular, o ônus probatório da culpa daquele indivíduo.

Nesse sentido, tal princípio só veio a ser explícito no texto constitucional, com a Constituição de $1988 \mathrm{em}$ seu artigo 5, inciso LVII. Antes, contudo, já se valia de sua utilização no processo de maneira implícita, uma vez que era aspecto do sistema processual. Dessa forma, a constituição estabeleceu que o limite da presunção de inocência que se vale a parte no processo é o trânsito em julgado da sentença condenatória. ${ }^{15}$ Isto é, não se fala em culpa, antes do transito em julgado da determinação do juiz a que emana a sentença condenatória, findando a presunção de inocência que reveste a parte.

\footnotetext{
${ }^{15}$ TÁVORA, Nestor e ALENCAR, Rosmar Rodrigues. Curso de Direito Processual Penal. Editora JusPodivm. p. 71.
} 
Tal determinação, possui como alicerce a concepção de que a liberdade é a regra, devendo esta ser cerceada apenas quando da convicção da necessidade da prática do poder punitivo que detém o Estado. ${ }^{16}$

Dessa maneira, Nestor Távora e Rosmar Rodrigues Alencar, em seu livro de Direito Processual Penal, trazem a definição precisa de George Sarmento ${ }^{17}$, sobre o princípio da presunção de inocência e sua aplicação, no qual é necessário "Cristalizar a presunção de inocência como um direito fundamental multifacetário, que se manifesta como regra de julgamento, regra de processo e regra de tratamento".

O que se cria, então, é, segundo o mesmo autor, "um amplo aspecto de garantias processuais que beneficiam o acusado durante as investigações e a tramitação da ação penal", sem que com isso se impeça "que o Estado cumpra sua missão de investigar e punir os criminosos, fazendo uso de todos os instrumentos de persecução penal previstos em lei”.

É irrefutável diante do apresentado a importância de tal princípio para a caracterização de um estado que de fato zele pela sua legalidade. Tal princípio, implica automaticamente na vedação de uma série de medidas que poderiam vir a ser tomadas de maneira arbitrária, como por exemplo a possibilidade de um encarceramento, legitimado pelo Estado, sem que mesmo houvesse os requisitos necessários a esse.

Nesse sentido, adentramos à análise do princípio da imparcialidade do juiz, elemento chave para sedimentação de que de fato, pode-se constituir um o ideal de uma justiça efetiva. Isso porque, a imparcialidade do juiz é o que funda o juízo de mérito e legitima sua capacidade e competência para a tomada de decisão.

O juiz imparcial, posto isso, é aquele que não apresenta tendência em relação ao objeto a ser tratado na decisão ou parte no processo, guiando-se, contudo, em acordo com os valores e princípios que conduzem do direito e as leis vigentes.

\footnotetext{
${ }^{16}$ TÁVORA, Nestor e ALENCAR, Rosmar Rodrigues. Curso de Direito Processual Penal. Editora JusPodivm. p. 71.

${ }^{17}$ Ibid. p. 72.
} 
$\mathrm{O}$ artigo $5^{\circ}$ da CRFB/88, apresenta em seus incisos XXXVII e LIII que não haverá tribunal de exceção, bem como que ninguém será julgado e sentenciado senão pela autoridade competente. Nesse sentido, é correto afirmar que a figura do juiz se torna imprescindível para a correta persecução do ideal da justiça, sendo meio pelo qual esse se encontra perfeito. Ora, não é possível haver jurisdição sem que haja autoridade julgadora, bem como não haverá tribunal que se constitua por causas circunstanciais para que se julgue o mérito.

Frisa-se aqui, que tal prerrogativa também é abarcada pela Declaração Universal de Direitos do Homem, sedimentando tal prerrogativa como direito fundamental base. Determina, posto isso, em seu artigo X:

"Todo ser humano tem direito, em plena igualdade, a uma justa e pública audiência por parte de um tribunal independente e imparcial, para decidir seus direitos e deveres ou fundamento de qualquer acusação criminal contra ele."18

Com efeito, é necessário que se traga à análise, também, o artigo 95 da CRFB/88, uma vez que determina as garantias concedidas aos juízes, e as prerrogativas pelas quais devem se guiar no exercício da função. Assim, são revestidos pela vitaliciedade, inamobilidade e irredutibilidade de subsídio, protegendo assim a motivação do seu juízo decisório.

As vedações trazidas por tal artigo também são de importância, ajudando a isolar possíveis causas de motivação pessoal que o juiz possa vir a ter em relação ao exercício de sua jurisdição, tamanha a importância que esse fato não ocorra.

É imperativo que se aponte, também, que tal imparcialidade mostrase fundamental para que se assegure a livre motivação do juiz, que também configura base principiológica do devido processo legal que, ao vedar interferências externas ao caso a ser ponderado, permite que o magistrado se guie mediante a própria autonomia de sua moral. Só assim, se vislumbra a possibilidade da efetivação de uma decisão de seja de fato justa.

\footnotetext{
${ }^{18}$ Declaração Universal dos direitos do homem, disponível no site da UNICEF
} 
Nesse sentido, vale ressaltar que apesar da vedação à interferência externa, o magistrado vale-se de todo seu constructo intelectual para a melhor tomada de decisão. Assim sendo, traz-se o entendimento de Simone Schreiber a respeito do tema:

"Não se pode negar que os juízes possuem, cada qual, condicionamentos políticos, ideológicos e culturais, que determinam o modo como percebem e compreendem as coisas do mundo. E que as subjetividades influenciam a forma como cada juiz aprecia a causa e forma sua convicção."19

Dessa forma, a lei também impede que o juiz exerça outro cargo ou função; o recebimento a título ou pretexto, bem como qualquer custa de participação em processos; dedicar-se à atuação política; receber qualquer provento de pessoas físicas, entidades públicas ou privadas, ressalvadas as exceções trazidas em lei; exercer a advocacia no juízo ou no tribunal do qual se afastou decorrido três anos do afastamento, exoneração ou aposentadoria. Tudo isso, no intuito de que se isole ao máximo a tomada de decisão.

Tal princípio é tão imprescindível para que se perfaça o ideal democrático da justiça, que os códigos de processo civil e penal trouxeram, na forma da suspeição e do impedimento, figuras responsáveis pelo afastamento do juiz, diante do caso concreto, quando se observa conflito de interesses ou causas que possam a vir causar decisões tendenciosas.

Faz sentido, então, que se traga o explanado pelos professores Nestor Távora e Rosmar Rodrigues Alencar em seu livro de direito processual penal. Determinam assim:

"Vale dizer, a isenção preconizada no ordenamento jurídico implica na postura de um magistrado que cumpra a Constituição, de maneira honesta, prolatando decisões suficientemente motivadas. Isso não induz que o juiz se abstraia de seus valores para que exerça seu mister" 20

Assim, adentramos à análise do princípio do Devido Processo Legal, lecionado pelo artigo $5^{\circ} \mathrm{em}$ seu inciso LIV, determina para que se justifique qualquer privação da liberdade, que como já apreciado, configura-se como

\footnotetext{
${ }^{19}$ SCHREIBER, Simone. A Publicidade Opressiva de Julgamentos Criminais. Rio de Janeiro: Renovar, 2008, p. 212.

${ }^{20}$ TÁVORA, Nestor e ALENCAR, Rosmar Rodrigues. Curso de Direito Processual Penal. Editora JusPodivm. p. 73.
} 
imposição que se opera em exceção sob qualquer indivíduo, deve esse possuir o direito ao devido processo legal.

Falar em devido processo legal, não implica somente neste ideal como um direito. $\mathrm{O}$ que se pretende determinar com isso, é que todo o réu possui a garantia de que, para que se justifique a legitimidade do poder punitivo do Estado sobre o mesmo, este passará por um processo pelo qual serão produzidas provas, que determinarão a materialidade e a autoria do fato, bem como será concedida o direito de uma defesa justa e proba, no qual tem-se o direito ao contraditório, e que todos esses fatos sejam analisados por um juiz imparcial e livre na sua vontade.

Dessa maneira, ao se determinar o conceito que abarca o devido processo legal, abrange, não apenas a representação de tal direito à esta própria prerrogativa, mas também à todas as outras que alicerçam os direitos da persona em si quando se remete ao âmbito processual. É, nesse contexto, falar do todo que reveste de legitimidade o poder do Estado de punir, e a jurisdição a que se sujeita o réu enquanto parte processual.

José Herval Sampaio Júnior ${ }^{21}$, traz clareza ao tema, quando ensina que:

"Vê-se que esse princípio assume dentro do processo uma importância transcendental e que delineia todo o seu agir, limitando inclusive a atividade do legislador, porquanto, deve a lei se conformar com os direitos e garantias fundamentais do cidadão, não havendo lugar para a interferência no núcleo protetivo da liberdade do agente, sem que sejam observados os condicionamentos e limites que decorrem da cláusula due process of law."

Diante do explanado, traz-se à tona dois dos princípios que integram justamente a garantia do devido processo legal, o direito ao contraditório e à ampla defesa. Assim, assegura-se sua tutela, a toda parte no processo, por meio do expresso no artigo $5^{\circ}$ da $\mathrm{CRFB} / 88$, em seu inciso LV.

O direito ao contraditório, só ingressou no ordenamento jurídico brasileiro de maneira positivada, mediante sua inclusão na Constituição de 1988, que conferiu a qualidade de "direito de primeira geração, de proteção

\footnotetext{
${ }^{21}$ SAMPAIO JUNIOR, José Herval. Processo Constitucional: nova concepção de jurisdição. São Paulo: Método, 2008. p. 137.
} 
à liberdade". Assim, existiu antes atuando como preceito regente do processo, como no caso do princípio da presunção de inocência.

Ao imbuir à parte no processo o direito ao contraditório e à ampla defesa, o legislador concede expressamente o direito dessa parte a poder influenciar na tomada de decisão do juiz. Abrange-se, dessa maneira possibilidade de provar os fatos alegados, ou desmentir o atestado contra si, bem como a capacidade de alegar, manifestar-se no curso processual, ser cientificado das decisões prolatadas pelas autoridades, no que diz respeito à sua esfera de direitos, bem como de realizar todos os atos, desde que em conformidade com a lei, necessários à persecução de seus direitos.

É, dessa maneira, a chance concreta de que a parte dispõe de utilizar de todos os meios e recursos, de maneira proba, a que dispõe, para provar os fatos alegados, ou restá-los refutados, é um princípio protetivo a que gozam as partes para que se questionem os fatos alegados.

As implicações decorrentes desse fato são a possibilidade que aquela parte processual detém de gerar consequências, por meio da influência no curso do processo, em sua própria esfera de direitos. ${ }^{22}$

Contudo, tal princípio não pode ser confundido com a ampla defesa, uma vez que esse se destina à tutela dos direitos da parte ré no processo. É preciso frisar, que além de ser aspecto de garantia do devido processo legal, uma vez que a apresentação da defesa impede que sejam cometidas arbitrariedades sem a efetiva apuração dos fatos, é também meio de equiparação dos poderes desempenhados pelas partes no processo.

Fala-se isso, uma vez que o réu, como natural de sua posição, goza de uma relação de inferioridade, no que tange ao poder exercido, em relação à figura do Estado, que atua no processo como ente detentor do direito de punir. Conceder a possibilidade de uma defesa justa, nada mais é do que garantir que haja paridade de armas entre qualquer cidadão e tal entidade.

2222 TÁVORA, Nestor e ALENCAR, Rosmar Rodrigues. Curso de Direito Processual Penal. Editora JusPodivm. p. 75. 
Assim, engloba tal princípio a defesa técnica, exercida pelo advogado profissional do direito, e a possibilidade da autodefesa, realizada pelo próprio indivíduo.

Em última análise, traz-se aqui o princípio processual constitucional que será fruto de maiores deliberações pelo presente trabalho, o princípio da publicidade. $\mathrm{O}$ artigo $5^{\circ}$ da $\mathrm{CRFB} / 88$, em seu inciso LX, determina que só poderá haver restrição da publicidade dos atos processuais, quando houver os requisitos expressos de proteção à intimidade e de resguarde do interesse social.

Ao determinar que assim fosse o legislador determinou que a publicidade dos atos no processo opera como regra. O que veio a ser corroborado pelo artigo 93, inciso IX, do mesmo texto constitucional, que determina que:

“todos os julgamentos dos órgãos do Poder Judiciário serão públicos, e fundamentadas todas as decisões, sob pena de nulidade, podendo a lei limitar a presença, em determinados atos, às próprias partes e seus advogados, ou somente a esses, em casos nos quais a preservação do direito à intimidade do interessado no sigilo não prejudique o interesse público à informação"

Infere-se então, que, muito mais que um princípio que integra a esfera do devido processo legal, a publicidade perfaz também o ideal democrático, que zela pelo interesse público de acesso e direito à informação. Contudo, tal direito não é exercido indistintamente, havendo limitações para que esse ocorra sem que com isso precise ferir esfera de direito alheia.

Isso porque é imprescindível que, para que haja a segurança da materialização do efetivo contraditório e do direito de defesa, a estabilidade processual e a imparcialidade do juízo não sejam afetadas durante o curso do processo.

Deve-se notar que tal princípio também foi incorporado nos códigos de processo penal, por meio de seu artigo 20, e de processo civil de 2015, em seus artigos 11 e 189, que também estabelece a limitação da publicidade de tais atos processuais em acordo com a especificidade do processo, elencado, dessa maneira, um rol constante do artigo 189 do Código de Processo Civil. 
É preciso que se lembre também, que tal princípio foi incorporado no Pacto de São José da Costa Rica, que, por meio de seu artigo $8^{\circ}$, número 5 , determinou a publicidade do processo penal como regra, excetuando-se os casos em que for necessária a preservação dos interesses da justiça.

Com efeito não se pode negligenciar que os fatos abarcados em determinados processos, transcendem a esfera privada, atingindo também a sociedade a depender do objeto ali tratado. Não se pode deixar de levar em conta o princípio do melhor interesse social nesses casos, mas, não se pode esquecer também, que este se encontra concretizado quando da garantia dos direitos constitucionais.

Tal princípio não pode restar subestimado em sua importância, uma vez que se consagra por ser meio pelo qual a sociedade percebe os atos do poder judiciário, sendo meio importante para a atuação da cidadania e sedimentação da democracia.

Além do que, ao se falar em mais um grau de vigília sobre as ações jurídicas, fala-se também em salvaguardar os mesmos em relação a qualquer arbitrariedade que possa a vir ser cometida, resguardando-os de segurança e revestindo-os pela garantia de legalidade.

O que não se pode admitir, é que, por meio de um princípio que possui como escopo alicerçar e consagrar um Estado Democrático de Direito, seja sabotada a possibilidade e o direito a que tem garantidos os réus mediante o processo.

O cerne do problema se encontra no fato de que o apelo que a publicidade de informações processuais possui vai além do conhecimento do particular a respeito das informações dos atos jurídicos praticados. Se encontra, tão somente, no fato de que a veiculação dessas informações em plataformas midiáticas, que se constroem sobre histórias apelativas, que não são regidas pelos mesmos valores como a imparcialidade e a limitação de divulgação, com vista a não interferir no desfecho processual, é responsável pela formação de opinião social sobre temas que ainda estão sendo discutidos. 
As implicações disso são a violação clara e direta do princípio da presunção de inocência, do devido processo legal e do contraditório e da ampla defesa, na medida que a criação dessa consciência coletiva a respeito de como o direito deve ser aplicado é óbice direito à imparcialidade do juízo e da livre motivação das decisões.

Além do que é preciso que se se considere que, mesmo diante da absolvição no meio jurídico de um processo com essas características, a sentença condenatória acaba por ser cumprida de maneira extralegal, por meio da qual a sociedade acaba por impor suas próprias penas. 


\section{CAPÍTULO 2. Princípio Da Publicidade e Da Transparência.}

\subsection{Limitação da imprensa: Ther trial by the mídia e o ideal democrático.}

Conceber qualquer espécie de limitação midiática quando se leva em conta um país com a democracia tão nova quando a brasileira, de certo, é um tema delicado.

Contudo, é necessário que se tome consciência dos processos que envolvem o momento histórico-social no qual ingressamos. Isso porque, o intenso fluxo de informação disponível a todo momento, proporcionou, na esteira da facilidade ao acesso do conhecimento, uma superexposição da vida privada.

As consequências dessa exposição, refletem, não somente na vida cotidiana, como também na maneira com que as informações são transmitidas e recebidas, acarretando em uma construção midiática cada vez mais sensacionalista e construtora dos "escândalos" noticiados, na qual a primazia da transmissão de informações e de fatos foi preterida à título da comercialização das mesmas como produto.

O que se deve observar é que a exploração das paixões se tornou um meio de manutenção e de sustento das empresas da mídia. Tal assertiva sustenta-se na compreensão de que o acesso à informação se dá de uma maneira tão democrática e acessível, que o apelo se faz necessário para a monetização do conhecimento, ou da informação.

Vê-se isso justamente quando se observa os contornos extremados que assumem as maneiras com que se anunciam as informações. São constatadas diante de técnicas como o clickbait (caça clique), por exemplo, que estampam as matérias jornalísticas títulos ou imagens extremamente sensacionalistas, mas que nem sempre correspondem ao conteúdo ali explanado, induzindo o leitor à erro em muitas vezes, com o propósito da maior comercialização de revistas, jornais, ou a título de aumentar o acesso aos sites, ou pontos de audiência televisivos. 
Sustenta, diante disso, Luiz Flávio Gomes:

"Não existe "produto" midiático mais rentável que a dramatização da dor humana gerada por uma perda perversa e devidamente explorada, de forma a catalisar a aflição das pessoas e suas iras. Isso ganha uma rápida solidariedade popular, todos passando a fazer um discurso único: mais leis, mais prisões, mais castigos para os sádicos que destroem a vida de inocentes e indefesos. As vítimas (ou seus familiares), a população e a mídia, hoje, constituem o motor que mais impulsiona o legislador (e, muitas vezes, também os juízes). É, talvez, a corrente punitivista mais eficiente em termos de mudanças legislativas, que tendem a aceitar o clamor público por penas mais longas, cárceres mais aviltantes, eliminação das progressões de regime, cumprimento integral da pena, nada de reinserção nem permissões penitenciárias, saídas de ressocialização, etc."’23

O deslinde fático dessa constatação, no que se refere aos fatos jurídicos, é a divulgação de provas, ou fatos constantes do processo ou do inquérito, como se tais gozassem de título verdadeiro e comprovado, o que muitas vezes não reflete o caráter desses elementos, que nem sempre restam atribuídos de genuinidade.

A gravidade da perspectiva dessa divulgação não afeta apenas no que concerne a veracidade daqueles elementos divulgados, mas também a relação que se cria com a apresentação de tais documentos.

$\mathrm{O}$ que se infere dessa assertiva é que cria-se um ambiente no qual o próprio receptor daquele conteúdo é integrante de um corpo de "júri social", e que, posto isso se sujeita ao convencimento, no que diz respeito à culpa daquele indivíduo, alvo da campanha midiática, por meio da arguição de acusação da reportagem, que incorpora função de órgão de acusação.

Assim, aniquila-se a pretensão de que, por exemplo, a presunção de inocência seja assegurada, aumentando a mentalidade de uma "vingança social", que em nada reflete o que de fato se caracteriza como justiça.

$\mathrm{O}$ que se pretende fazer notar, não é a verossimilhança, ou a comprovação dos fatos ocorridos e amplamente divulgados, uma vez que esses aspectos são irrelevantes diante do discutido e suas consequências. Além do que, é cediça a realidade política atual, bem como a realidade concernente à segurança nacional.

${ }^{23}$ LACERDA, Juliana Andrade. Análise Crítica acerca da Influência da Mídia no Processo Criminal Brasileiro.Escola da Magistratura do Estado do Rio de Janeiro 
Dessa forma, o que se pretende contestar na verdade é que, a título da maior comercialização de informação, na qual faz-se cada vez mais necessária a faceta apelativa, os veículos midiáticos criam e formam a opinião social a respeito de fatos que não foram ainda apreciados pelo judiciário.

Acaba-se, diante disso, colocando em xeque todos os princípios, já aqui explanados, liquidando o devido processo legal e a possibilidade de uma justiça democrática.

Quando se fala na concretização de uma justiça democrática, parte-se da premissa de que o processo deve-se equivaler em sua tramitação a todos aqueles que são polos de sua incidência. O juízo decisório deve ser revestido também de garantia de legalidade, a que se efetiva por meio da observação das fontes do direito, isto é, a Lei, a doutrina, a jurisprudência, visando assim a estabilidade das decisões proferidas.

A justiça exercida de maneira democrática, posto isso, nada mais é que o resguarde dos fundamentos da república, consagrados pelo artigo primeiro do texto constitucional, sendo imprescindível para que exista fé pública nas ações do Estado.

É necessário, dessa forma, que se traga, à luz dos fatos aqui sustentados, o que se entende como o ideal do Estado de Direito.

Assim, Lenio Luiz Streck e José Luis Bolzan de Morais, ensinam com precisão que:

"o Estado de Direito surge desde logo que o Estado que, nas suas relações com os indivíduos, se submete a um regime de direito, quando, então, a atividade estatal apenas pode desenvolver-se utilizando um instrumental regulado e autorizado pela ordem jurídica, assim como os indivíduos - cidadãos - tem a seu dispor mecanismos jurídicos aptos a salvaguardar-lhes de uma ação abusiva do Estado"24

A pretensão aqui, então, é a discussão do que de fato convalida o ideal democrático, diante do choque entre tais preceitos, vez que os dois, isto é, o acesso à informação - que engloba tanto o direito à receber a informação, tanto a liberdade de expressão dos veículos midiáticos em transmitir a

\footnotetext{
${ }^{24}$ GRECO, Rogério. Curso de Direito Penal - Parte Geral. Editora Impetus. p. 143.
} 
informação - e a garantia do devido processo legal, asseguram um direito e uma república alicerçada sobre bases democráticas.

O papel desempenhando pela mídia, além disso, é de imprescindível valor, vez que, como aqui já exposto, é meio de fiscalização do judiciário. Destaca-se também, a qualidade de meio para o exercício da cidadania, já que permite a conexão direta do indivíduo com os acontecimentos de interesse público.

Exemplo claro desse fato, é a existência da TV Justiça que, embora não se assemelhe aos casos narrados aqui pela inexistência de seu caráter apelativo-jornalístico, foi um meio televisivo utilizado para democratizar o acesso ao judiciário, tornando-o realidade mais acessível, propiciando uma maior aproximação em relação aos assuntos tratados na plenária do Supremo Tribunal Federal.

O importante, diante disso, é entender que, do confronto de tais preceitos, não existe choque, apenas a ponderação do que concerne a tutela do bem público e do privado.

No que tange o confronto de princípios constitucionais, já afirmamos o entendimento de que sua solução se dá diante da análise do caso concreto, no qual se fará evidente qual o caminho a ser seguido. Afirma-se isso uma vez que o direito à privacidade só poderá ser suprimido quando por exigência de saciar o interesse público.

É necessário que se elucide que quando se fala em demanda do interesse público se fala na verdade na hipótese dos fatos tratados naquele processo extrapolarem a esfera de interesse das partes que o integram, tratando também de assuntos que demandam a esfera de direitos públicos.

Faz-se assim imperativo que processos que tenham em seu conteúdo substância política, como os que tratam sobre matéria de improbidade administrativa, ou de saques aos cofres públicos, ganhem peculiar apelo nessas circunstâncias, já que versam sobre bens públicos, logo, devem ser de conhecimento geral. 
Contudo, a questão aqui colocada, não é sobre o fato de que as mídias possibilitam que esses casos ganhem contornos públicos diante de reportagens realizadas a respeito dos mesmos, mas sim dizem respeito as críticas e opiniões casadas as essas reportagens, realizando, dentro da própria matéria apresentada, o julgamento do caso em acordo com os pensamentos pessoais daquele veículo midiático ou daquele que escreve a reportagem.

É assim que se cria o que se chama de Trial by the mídia. Tal expressão refere-se ao julgamento prévio realizado por veículos de informação a respeito de determinado caso.

Dessa maneira, muito além do que se posicionar a respeito de determinado tema, o Trial by the mídia determina o abuso de poder, diante da plataforma que detém os jornais, revistas, programas televisivos e personalidades influentes, produzidas pela internet, diante do caso ali discutido.

Assim, o conceito é definido por Márcio Thomaz Bastos:

"É o processo pelo qual o noticiário da imprensa sobre as investigações em torno de uma pessoa que vai ser submetida a julgamento acaba determinando a culpabilidade ou a inocência da pessoa antes dela ser julgada formalmente" 25

Nesse sentido, a tese apresentada pela magistrada Simone Schreiber ganha particular relevância nesse contexto. Em seu livro "A Publicidade Opressiva de Julgamentos Criminais.", Schreiber aponta uma série de medidas que pode dispor o juiz, quando do conflito desses dois princípios constitucionais, hierarquicamente correspondentes. ${ }^{26}$

Dessa forma, o que deve ser observado é a configuração no caso concreto do Trial by the mídia, no qual a publicização dos fatos processuais, isto é, o exercício da liberdade de expressão e do direito à informação, estariam minando diretamente a possibilidade do julgamento justo.

\footnotetext{
2514 BASTOS, Márcio Thomaz. Júri e Mídia. Tribunal do Júri: Estudo sobre a mais democrática instituição jurídica brasileira. São Paulo: Revista dos Tribunais, 1999, p. 115-116.

${ }^{26}$ Disponível em: https://www.conjur.com.br/2009-jun-07/juizes-conviver-pressao-critica-meioscomunicacao. Acesso em: 19 out. 2018.
} 
Nesse diapasão, a juíza sustenta que o magistrado, ao perceber tais aspectos, poderia, a fim de não restringir a liberdade de imprensa, adiar o julgamento, até que este já não mais sofresse dos holofotes midiáticos, bem como a modificação do local do julgamento, para que seja diferente do local em que o fato criminoso ocorreu.

Outra medida, também sustentada pela autora é a vedação da utilização das provas produzidas pelos veículos de informação, uma vez que, em muitos casos, são produzidas de maneira ilícita. A exemplo, uma escuta implantada de maneira ilegal não poderia restar como fruto comprobatório na tribuna, sob qualquer prerrogativa, não importando os fatos que tal prova restassem comprovados.

Deve-se ainda salientar que tais medidas apenas contribuem para esclarecer a ameaça representada por tais reportagens, uma vez que não há livre convencimento que suporte a parcialidade sustentada por inúmeras fontes de notícia, que a todo momento atacam os meios de comunicações com notícias "urgentes" a respeito dos casos sob holofotes.

Fato que influencia, não somente o magistrado, como também os jurados, no caso do processo criminal de crime doloso contra a vida, que são sujeitos à doutrinação de toda natureza diante da sede para destrinchar os casos veiculados.

A pressão social que incide sobre o juiz também deve ser levada em consideração, nesse aspecto, uma vez que acarreta repercussões em sua vida pessoal. É nesse sentido que uma decisão que não favorece o apelo público, mas encontra-se em conformidade com a lei, pode sentenciar a opinião pública diante daquele magistrado, determinando sua probidade ou competência para atuar.

É importante que se entenda que as consequências que se põe sob ponderação não dizem respeito apenas aos desdobramentos jurídicoprocessuais dos processos ou inquéritos, uma vez que essas extrapolam o âmbito do julgamento proporcionado pelo Estado. 
A chaga mais profunda que se apresenta pela efetivação desse juízo social se apresenta depois de superada a questão jurídica. Ela afeta a possibilidade de continuidade da vida, impedindo a consubstanciação do direito ao esquecimento, impossibilitando a reintegração social.

Com efeito, tal realidade é ainda maior na atualidade, uma vez que, muito dificilmente, pode-se retirar alguma informação do âmbito virtual, bastando apenas uma pesquisa para que se identifique todas as informações acerca da vida de qualquer indivíduo, seja ela realidade ou não.

Cria-se, muito mais do que um juízo julgador, formula-se um constructo de juízo de vingança social, sob a possibilidade de se ver concretizados os anseios próprios individuais, que se regem pelo fluxo histórico-social determinante de cada época em que não há absolvição e as penas podem ser de caráter perpétuo.

\subsection{Pertinência Político-social da divulgação de informações processuais e a ponderação de princípios.}

O substrato que decorre dos fatos arguidos até o momento é acerca da fundamentação necessária para a relativização de preceitos fundamentais, bem como a justificativa pertinente para que se suprima ou diminua uma garantia em razão de outra, em vistas de manter a salubridade de um sistema jurídico democrático.

Antes de mais nada é primordial que se esclareça que veículos midiáticos se constituem por meio de empresas. Tal entendimento faz-se vital, na medida de que desse fato decorre a percepção basilar de que, como qualquer empresa, essa rege-se por parâmetros, diretrizes e ideologias próprias

Não é razoável que se pretenda que reportagens não devam ser carregadas desses aspectos, uma vez que também são incumbidas de sustentar a base ideológica defendida por aquela determinada empresa. Não se pode, contudo, confundir a incorporação de determinadas diretrizes e princípios com a parcialidade tendenciosa e despojada de contornos éticos. 
Outro fator passível de análise é a rapidez pela qual se qualifica a informação, e sua dinamicidade. Fala-se isso, uma vez que o acesso à informações, fatos e acontecimentos, se dá e se transmite de maneira quase que instantânea, no momento em que se dá a ocorrência dos fatos. Tal aspecto contribui para a relativização do conteúdo divulgado, bem como a falta de análise e estudo sobre o que é transmitido.

A autora Simone Schreiber afirma, sobre o assunto, que ${ }^{27}$ :

"O valor velocidade substituiu o valor veracidade. Fica inviabilizada qualquer análise mais cuidadosa dos fatos noticiados. O resultado é o recurso a estereótipos para explicação da realidade. A pressa exige ainda que o jornalista utilize um número limitado de fontes, pois a diversificação possibilita o acesso a informações eventualmente contraditórias, o que dificulta a generalização de dados e a redação da notícia no exíguo tempo disponível."28

Exemplo disso, é a operação Lava-jato, televisionada e noticiada ao extremo. Em virtude disso, suas atribuições e decisões foram transmitidas, praticamente, em tempo real para os espectadores, bem como as prisões e mandados, realizados pela operação, acompanhados ao vivo pelos telespectadores e internautas. O fenômeno se deu de uma maneira tão abrangente, que os agentes da polícia federal que realizaram os atos designados da operação, tornaram-se verdadeiras celebridades.

Dá-se aqui especial atenção à prisão de Luiz Inácio Lula da Silva, que entregou ao vivo todo o caminho percorrido pelo ex-presidente até a Superintendência Regional da Polícia Federal no Paraná, fazendo-se uso de drones, helicópteros e dispositivos eletrônicos.

Fala-se aqui sobre um processo ainda não transitado em julgado que cominou na prisão de um presidente por lavagem de dinheiro. Não há dúvidas, no que tange à matéria processual tratada, de que residia ali questão de interesse público, já que tais crimes foram cometidos na gestão do réu como Presidente do país.

\footnotetext{
27 SCHREIBER, Simone. A Publicidade Opressiva de Julgamentos Criminais. Rio de Janeiro: Renovar, 2008, p. 359.

${ }^{28}$ LACERDA, Juliana Andrade. Análise Crítica acerca da Influência da Mídia no Processo Criminal Brasileiro.Escola da Magistratura do Estado do Rio de Janeiro.
} 
Destaca-se, que tal acontecimento não salta aos olhos somente em virtude dos motivos que cominaram na prisão, mas também pelo fator histórico e inédito, uma vez que, pela primeira vez o aparato jurídico do Judiciário manejou de comprovar e vincular à uma figura política, que já ocupou a chefia do Poder Executivo do país, crimes de natureza pública, resultando no cumprimento fático de pena restritiva de liberdade e ressarcimento ao erário.

Contudo, argui-se também sobre as hipóteses nas quais não é evidente de maneira tão cristalina o liame entre interesse público e proteção do direito à privacidade.

É assim, que se traz o entendimento de Luiz Roberto Barroso sobre o tema de ponderação de princípios constitucionais:

Como não existe um critério abstrato que imponha a supremacia de um sobre o outro, deve-se, à vista do caso concreto, fazer concessões recíprocas, de modo a produzir um resultado socialmente desejável, sacrificando o mínimo de cada um dos princípios ou direitos fundamentais em oposição. ${ }^{29}$

Nesse sentido, não cabe a construção de teorias de maneira abstrata acerca do tema, já que a elucidação se apresenta de fato diante do caso concreto. Fala-se isso, uma vez que apenas diante da situação fática é que se pode entender o que favorecerá de fato o interesse das partes, ou que diminuirá, ou não causará, lesão aos envolvidos.

Determinar o afastamento ou restringir a aplicabilidade de um princípio constitucional de maneira abstrata traça precedente para uma série de arbitrariedades que podem vir a ser cometidas, sem que para tanto haja real justificativa. Tal hipótese não pode ser concebida, uma vez que é da natureza de tais prerrogativas serem inalienáveis, dessa maneira, a regra é a da impossibilidade do afastamento da incidência desses princípios.

Entende-se, que não apenas os casos que tangem a administração pública, como o supracitado, despertam o interesse midiático. Como já sustentado, a exploração das paixões sociais é muito cobiçada uma vez que

${ }^{29}$ LACERDA, Juliana Andrade. Análise Crítica acerca da Influência da Mídia no Processo Criminal Brasileiro.Escola da Magistratura do Estado do Rio de Janeiro. 
toca o sensacionalismo, acarretando uma maior monetização do conteúdo veiculado. Destarte, temas vinculados à morte, à barbárie, ao sexo, e ao dinheiro, trazem muito apelo midiático.

Contudo, não se encontra justificativa para a alta cobertura midiática de processos que em nada resguardam conexão com a vida pública. Pelo contrário, tais veiculações induzem à uma consciência coletiva de maior periculosidade, até mesmo de perda de controle institucional sobre a segurança.

A constatação da realidade apresentada não só desencadeia o exposto, como também é responsável por propiciar a formação de um cenário que descredita a justiça e as instituições públicas pela sensação de "impunidade".

$\mathrm{O}$ cenário apresentado se materializa uma vez que nem sempre o interesse midiático se sustenta até o deslinde do processo, não informando ao receptor o desfecho da história que foi apresentada, o que acaba por atribuir uma impressão de insegurança e de não efetividade da justiça. O que normalmente ocorre é a sucessão de um caso por outro, contribuindo, ainda mais com essa percepção.

Importa em se fazer notar essa constatação, uma vez que, como já mencionado, a mentalidade da necessidade que se faça necessário o uso de uma "vingança social", é um dos principais atributos que são consequência da extrema exposição de fatos processuais, impondo óbices ao direito ao esquecimento e à manutenção de uma vida salubre, independentemente da constatação de culpa do indivíduo.

Assim, impera trazer o posicionamento da professora Sylvia Moretzsohn expõe que aduz a respeito de tema a seguinte assertiva ${ }^{30}$ :

"O ritmo veloz de produção gera ainda outras consequências importantes: obriga o repórter a divulgar informações sobre as quais não tem certeza; reduz quando não anula, a possibilidade de reflexão no processo de produção da notícia, o que não apenas aumenta a probabilidade de erro como, principalmente e mais grave, limita a possibilidade de matérias com ângulos diferenciados de abordagem, capazes de provocar questionamento no leitor; e talvez mais importante, praticamente

\footnotetext{
${ }^{30}$ MORETZSOHN, Sylvia. Jornalismo em Tempo Real: O Fetiche da Velocidade. Rio de Janeiro: Revan, 2002, p. 70.
} 
impossibilita a ampliação do repertório de fontes, que poderiam proporcionar essa diversidade" 31

O direito de defesa e a garantia de um processo justo não pode ser relativizado em um ordenamento jurídico que preze pela higidez de suas instituições e de sua base democrática. A garantia de prossecução do direito de se provar inocente é tão basilar que é inconcebível que se pense em um Estado democrático sem a salvaguarda do mesmo.

Sob última reflexão, traz-se a ponderação realizada pelos professores Ives Granda da Silva Martins, Renato de Mello Jorge Silveira e Hamilton Dias de Souza no artigo "Dignidade sob Pressão", publicado no jornal Folha se São Paulo:

"A investigação criminal é um instrumento legítimo de apuração de responsabilidade e de apoio a justiça no julgamento regular das pessoas suspeitas, requerendo responsabilidade no seu tramite. Deve ser conduzido com imparcialidade, impessoalidade e equilíbrio, para trazer à luz fatos e dados que conduzem a um julgamento justo." 32

Impera que se pondere, posto isso, o que de fato norteia a pertinência jurídico-social em tal visibilidade processual. Para tanto, ingressaremos à análise de processos que sofreram com tal incidência, para melhor entendimento da tese aqui proposta.

${ }^{31}$ LACERDA, Juliana Andrade. Análise Crítica acerca da Influência da Mídia no Processo Criminal Brasileiro.Escola da Magistratura do Estado do Rio de Janeiro.

${ }^{32}$ Jornal Folha de São Paulo. Tendências/debates. Dignidade sob pressão. 06 de Novembro de 2018. 


\section{CAPÍTULO 3. Estudo de Caso}

\subsection{Luiz Inácio Lula da Silva e a Operação Lava-Jato}

Iniciaremos o estudo de caso por meio da análise do processo de Luiz Inácio Lula da Silva, e suas repercussões no direito brasileiro, inclusive, para a elaboração de nova jurisprudência e doutrina sobre a matéria tratada no processo. Assim sendo é necessário que se elucide as bases do processo, sua acusação e a sentença proferida.

O tempo do crime pelo qual Lula foi acusado-se deu quando ainda ocupava a cadeira de chefia do Poder Executivo. Posto isso, as acusações deram-se mediante os crimes de corrupção ativa, falsidade ideológica e lavagem de dinheiro.

A indicação de Lula como réu no processo dá-se por meio do acordo de delação premiada realizado por José Aldemário Pinheiro, dono da empreiteira OAS, que na época era investigado sobre a suspeita existência de corrupção em contratos realizados com a empresa estatal Petrobras. Nesse sentido, sustenta a acusação que consistia o crime no pagamento do percentual de $2 \%$ a agentes públicos, agentes políticos e partidos políticos por meio de uma lógica de pagamento de propinas entre a OAS e o PT. ${ }^{33}$

O Ministério Público Federal ${ }^{34}$, dessa forma, oferece denúncia por meio da qual identifica Lula e sua esposa, Marisa Leticia, falecida em 2017, como verdadeiros proprietários de um imóvel no condomínio Solaris, em Guarujá, que se registrava como sendo da empreiteira, e supostamente teria sido dado a título de retribuição. ${ }^{35}$

Sustenta ainda, que não seria o caso de omissão praticada pelo réu, mas sim, de ter agido ativamente na realização de favores e facilitação de relações contratuais desenvolvidas junto à OAS, que em contrapartida,

\footnotetext{
${ }^{33}$ Disponível em: https://politica.estadao.com.br/blogs/fausto-macedo/delacao-de-leo-pinheiro-vaide-palestras-de-lula-a-doacoes-para-instituto/. Acesso em: 12 nov. 2018.

${ }^{34}$ Denúncia do Ministério Público Federal. Procuradoria da República do Paraná. Distribuição por dependência aos autos no 500661729.2016.4.04.7000/PR e 5035204-61.2016.4.04.7000/PR

35 Disponível em: https://exame.abril.com.br/brasil/a-linha-do-tempo-do-caso-triplex-que-levoulula-a-prisao/. Acesso em: 12 nov. 2018.
} 
concedia "presentes" ao réu. Nesse diapasão o Triplex na cidade de Guarujá foi dado como pagamento de propina, bem como as reformas realizadas nele, a exemplo da instalação de um elevador privativo, que segundo o Ministério Público Federal eram destinados à um cliente específico, no caso, o réu. ${ }^{36}$

O montante, contabilizando o preço do imóvel e as reformas realizadas nele, foram de 3,7 milhões em benefício próprio, do montante de 87 milhões de corrupção entre os anos de 2006 e 2012, tendo sido o imóvel utilizado para guardar os presentes ganhados pelo réu enquanto ocupava o posto de Presidente da República. Os benefícios mencionados, dessa maneira, consistiam no desvio de recursos dos contratos públicos realizados pela Petrobras, bem como a garantia de prioridade para tais pela OAS. ${ }^{37}$

A fundamentação do processo criminal resvala, principalmente, na delação prestada por José Aldemário Pinheiro. O réu, conhecido também como Léo Pinheiro, foi preso na Operação Juízo Final, $7^{\text {a }}$ fase da operação Lava-Jato, e condenado pela ação penal que julgou o pagamento de propina à Diretoria de Abastecimento da Petrobrás, em razão de contratos firmados com a Refinaria Getúlio Vargas (Repar) em conjunto com a Refinaria Abreu e Lima (Rnest). ${ }^{38}$

Por justamente firmar-se pela substância do relatado no depoimento do empreiteiro, não há indícios registrais que vinculem o nome do Lula ao triplex, uma vez que esse nunca foi transferido ao ex-presidente, permanecendo, no cartório de registro de imóveis como vinculado à OAS, que, segundo a acusação, valia-se da qualidade de "laranja" para que dessa maneira não deixasse traços que pudessem vincular a posse do Triplex à Lula. A acusação qualificou tal característica como tentativa de ocultação do patrimônio pelo réu, tomando como indício do crime de lavagem de dinheiro.

\footnotetext{
${ }^{36}$ Disponível em: https://politica.estadao.com.br/blogs/fausto-macedo/delacao-de-leo-pinheiro-vaide-palestras-de-lula-a-doacoes-para-instituto/. Acesso em: 12 nov. 2018.

37 Disponível em: https://politica.estadao.com.br/blogs/fausto-macedo/ex-diretor-da-oas-afirmaque-triplex-estava-reservado-a-lula/ Acesso em: 12 nov. 2018. Disponível em: https://g1.globo.com/politica/operacao-lava-jato/noticia/perguntas-e-respostas-sobre-acondenacao-de-lula-no-caso-do-triplex.ghtml. Acesso em: 12 nov. 2018.

${ }^{38}$ Disponível em: https://politica.estadao.com.br/blogs/fausto-macedo/delacao-de-leo-pinheiro-vaide-palestras-de-lula-a-doacoes-para-instituto/. Acesso em: 12 nov. 2018.
} 
As irregularidades apontadas por Léo Pinheiro em seu depoimento transcorreram nos contratos CONEST/RNEST e COMPAR, realizados entre o Grupo OAS e a Petrobras. As vantagens se deram de maneira direta ao PT e á base aliada, que também se valeram das benesses desse acordo, aliado à isso, o ganho se dava de maneira direta e pessoal ao réu, como bem mencionado, pela entrega de "presentes".

A Petrobras, pano de fundo no qual transcorreram os contratos investigados, já apresentava, muito antes das denúncias, sinais de má gestão. Foi assim que a realização de um balanço no ano de 2015 comprovou a realidade da crise enfrentada na empresa em razão do desvio de investimentos, contabilizando um prejuízo de cerca de 6 bilhões de reais a título de corrupção.

Dessa maneira, foi utilizado em juízo, como prova de autoria do crime, a falta de conhecimento do desvio apurado e a falta de reprovação aos agentes, julgados pela Ação Penal $470^{39}$ em 2013. Tal ação foi responsável pela análise e investigação dos crimes de corrupção ocorridos na Petrobras em sede do mensalão, assim, foi tomado como indício de conhecimento do réu a respeito das transgressões bem como de participação nos crimes. Falase aqui, na imputação de um crime sem a existência de provas, ou indicação de uma ação que determinasse a consumação da conduta.

Nesse sentido, a prova do fato concreto, isto é, a evidência da materialidade do crime de corrupção ativa e passiva, e a atuação do réu nos atos pelo qual foi acusado, restou-se preterida em razão da exposição das consequências do crime em tese e validando-se o uso de tal raciocínio como suficiente para a convalidação da sentença condenatória em pena restritiva de liberdade no caso do Triplex, como ficou conhecido.

Assim, no interrogatório conduzido pelo Juiz Federal Sérgio Moro, descreve a denúncia da seguinte maneira:

39

Disponível em: http://www2.stf.jus.br/portalStfInternacional/cms/destaquesNewsletter.php?sigla=newsletterPortal InternacionalNoticias\&idConteudo=214544. Acesso em: 12 nov. 2018. 


\begin{abstract}
"Senhor ex-presidente, essa acusação do Ministério Público tem basicamente duas partes, numa primeira parte o Ministério Público argumenta que o senhor teria conhecimento e participação em um esquema de corrupção que teria vitimado a Petrobras, com divisão de propinas entre diretores da Petrobras e agentes políticos. Numa segunda parte o Ministério Público argumenta que o senhor ex-presidente teria sido beneficiado pelo grupo OAS com vantagem indevida de cerca de 2 milhões e 424 mil reais, essas propinas seriam constituídas no repasse ao senhor de um imóvel consistente em um apartamento triplex 164A no Condomínio Solaris, no Guarujá, e a realização de reformas nesse apartamento. Segundo a acusação, o senhor ex-presidente teria pago nesse edifício por uma unidade simples, mas foi destinado pela OAS um apartamento triplex para o senhor, com três pavimentos, de preço superior, além do que teriam sido feitas reformas para incrementar esse apartamento sem que o senhor ex-presidente arcasse com a diferença de preço do imóvel e com o custo das reformas, essa vantagem indevida, segundo o Ministério Público, cerca de 2 milhões e 424 mil, estaria relacionada a acertos de corrupção em contratos públicos, inclusive da OAS com a Petrobras." ${ }^{40}$
\end{abstract}

Diante da elucidação do processo, passa-se ao estudo dos fatos processuais. Em primeira análise insta salientar que o réu, como figura pública, já residia sob os holofotes de noticiários muito antes de se tonar parte no processo em questão. Ocorre que, muito antes de iniciado o julgamento judicial pelos crimes denunciados, o cenário político-econômico nacional, demonstrava grande instabilidade.

É o que se pode perceber em decorrência das manifestações ocorridas em 2013, posteriormente conhecidas como Jornadas de Junho, prenunciando a mentalidade de descontentamento com as diretrizes nacionais. O movimento marcou a retomada da apropriação do discurso político, que não via fomento desde o processo de redemocratização e posterior impeachment de Fernando Collor enquanto presidente, em 1992.

A manifestação televisionada, com cenas fortes como a invasão ao prédio do Congresso Nacional em Brasília, bem como a atuação de Black Blocks, proporcionou uma impressão polarizada acerca do tema. Aliado a isso, a postulação realizada por esse movimento, isto é, a diminuição da passagem de transportes públicos, em conjunto com a devoção na manutenção da desvinculação partidária, é representativa da decadência e da falha de representatividade política no país.

\footnotetext{
${ }^{40}$ Termo de Transcrição da AÇÃO PENAL Nº 504651294.2016.4.04.7000/PR. Luiz Inácio Lula da Silva
} 
O retrospecto se faz necessário uma vez que, quando se analisa a abordagem de polarização realizada nesse período, cominada com o início da investigação de políticos do alto escalão do governo, começa-se a entender os contornos da importância, não só jurídica, como social desses casos. Dizse isso, uma vez que a atmosfera de descontentamento em produção, que encontrava resguardo na fragilidade econômica da época, otimizou o gatilho para a criação de uma mentalidade geral de descrença nas entidades públicas e na efetivação da justiça. É desse sentimento, que decorre o pensamento de justiça a qualquer custo, tão perigosa para os resguarde de direitos, que se tornam relativizados ao extremo.

O que se fala aqui é facilmente demonstrável quando traz-se à tona a figura dos jornais locais, ou até mesmo programas como Brasil Urgente, e Linha direta, que traziam, e ainda trazem, uma massificação de notícias a respeito de crimes, sejam esses comprovados ou não, aumentando a tensão social e dando causa à linchamentos públicos em todo o país. É assim que nos tornamos ao processo discutido, uma vez que este determinou o início do cotejo à justiça da expectativa e não do direito.

$\mathrm{Ab}$ initio, é preciso que se faça notar a garantia elencada no artigo $5^{\circ}$ da Carta Constitucional, em seu inciso LXXVIII, que leciona a respeito da duração razoável do processo. Mesmo nos guiando sobre a prerrogativa de que o rito processual deva zelar por tal garantia, a fim de não prejudicar o direito a que se visa resguardar, e, levando-se em conta o interesse público do julgamento de crimes que saquearam os cofres públicos, não se justifica a rapidez com que foram definidos os prazos do processo em análise.

Em uma aula pública ocorrida em Porto Alegre, o professor José Carlos Moreira, da PUC-RS, apontou que a revisão da sentença, realizada pelo Tribunal Regional Federal da $4^{\mathrm{a}}$ região, deu-se em período de férias coletivas da justiça, no dia 24 de janeiro de $2018^{41}$. A controvérsia reside

\footnotetext{
${ }^{41}$ É necessário que se frise que a Emenda Constitucional 45 vedou as férias coletivas nos Tribunais de $2^{\circ}$ grau desde 2004, como disposto no artigo 93, XII da Constituição Federal de 1988. Além disso, o Novo Código de Processo Civil suspendeu os prazos de 20/12 a 20/01, tendo a data do julgamento
} 
justamente no fato de que nenhum processo é julgado em tal período, já que não há qualquer atividade jurídica. ${ }^{42}$

Não é possível negar que, de fato, pode existir a inquisição a respeito da questão da res pública que encampa a matéria tratada no processo. Contudo, mesmo que se fosse ponderar acerca desse aspecto, não se observa, por exemplo, nos casos dos processos administrativos que recorrem à via judiciária, a mesma urgência de tratamento. E mesmo que seja analisada sobre o mesmo prisma, isto é, sob a ótica de outros processos de corrupção envolvendo políticos do alto escalão do governo na mesma operação, não há a ocorrência de tal característica célere em nenhum outro processo.

A presunção de inocência nesse caso é de especial relevância. Fala-se isso, uma vez que a campanha midiática sobre tal caso foi primorosa, sendo, somente no jornal O Globo ${ }^{43}$ desde o ano de 2010, cerca de 6 mil páginas a respeito do processo sobre as provas, os aspectos, as delações, depoimentos e possíveis decisões com as respectivas consequências sociais. Como já referido, a principal evidência sustentada por esse fenômeno, foi a conjuntura econômica do país, construída de maneira a depender do resultado do processo.

As matérias veiculadas sempre traziam informativos ligados à economia em conjunto ao avanço do processo. O que se traçou, a partir de tal colocação, foi a correlação entre o avanço da ação e a queda do dólar, como indicativo de progresso, e de que a persecução judicial desenvolvida no âmbito daquele processo, também traçava benesses ultra partes ${ }^{44}$. Quanto

sido no dia 24/01. Dessa forma, o Código de Processo Civil não se aplica diretamente ao processo penal, de modo que os prazos processuais penais não ficam suspensos nesse período.

42 Disponível em: https://www.brasil247.com/pt/247/brasil/334027/Erros-no-processo-deveriamanular-condena\%C3\%A7\%C3\%A3o-de-Lula-apontam-juristas.htm. Acesso em: 12 nov. 2018.

43 Disponível em: https://acervo.oglobo.globo.com/busca/?tipoConteudo=pagina\&pagina=\&ordenacaoData=relevanc ia\&allwords=Lula+lava+jato\&anyword $=\&$ noword $=\&$ exactword $=\&$ decadaSelecionada $=\&$ anoSele cionado $=\&$ mesSelecionado $=\&$ diaSelecionado=. Acesso em: 12 nov. 2018.

${ }^{44}$ Disponível em: https://g1.globo.com/economia/noticia/cotacao-do-dolar-060318.ghtml; https://economia.uol.com.br/cotacoes/noticias/redacao/2018/01/23/mercado-ve-julgamento-delula-como-divisor-de-aguas-para-o-futuro-do-pais.htm; Acesso em: 12 nov. 2018. Disponível em: https://oglobo.globo.com/economia/apos-condenacao-de-lula-dolar-fecha-em-316-bolsa-salta-37batendo-recorde-22321974. Acesso em: 12 nov. 2018. 
mais próximo à uma sentença condenatória encarceradora, melhor os indicativos econômicos e sociais, e maior a estabilização política. A atmosfera televisionada criou contornos novelescos, traçando a distinção de personagens clássicos maniqueístas, e estabelecendo paralelo entre a jornada do herói e a trajetória do juiz na elaboração da sentença.

A construção desse ideal elevado ao redor do caso foi de tal maneira abrangente que a prisão de um indivíduo se tornou sinônimo de recuperação de um país inteiro, não apenas no que tange a efetivação da justiça, mas como também a recuperação da crença na eficiência das instituições públicas que não mais eram alvo da fé pública. A perspectiva de que um juízo pudesse ser imparcial, motivado pela formação de sua experiência interna, bem como de seus valores, na busca da verdade real, sob tais circunstâncias, é quase impossível de se imaginar quando se colocava todas as expectativas de melhora nacional na efetivação de uma condenação.

Fato que sustenta tal afirmação, para além do explanado, foi o despacho determinando condução coercitiva do réu para depor, mesmo que sem a demonstração dos requisitos necessários para tanto. Marco Aurélio de Mello, ministro do STF, determina que a condução coercitiva "deve ser precedida pela recusa do intimado em comparecer perante a autoridade que deve ouvi-lo". 45

Não houve despacho anterior que tivesse intimado o réu a comparecer em juízo para prestar depoimento, não se justificando o uso de tal instrumento, contribuindo apenas para reforçar o ideal de eficiência esperado. Os contornos de uma assunção da competência inquisitória, pelo juiz, são demonstrados de maneira clara no presente caso.

Violação igualmente gravosa decorreu do estabelecimento de grampos telefônicos nos escritórios dos advogados de defesa do réu. O sigilo e a

\footnotetext{
Disponível em: https://www.valor.com.br/financas/5367047/dolar-tem-maior-queda-em-3semanas-com-julgamento-do-lula-e-exterior. Acesso em: 12 nov. 2018.

${ }^{45}$ Disponível em: http://agenciabrasil.ebc.com.br/politica/noticia/2016-03/conducao-coercitiva-delula-provoca-debate-sobre-coercao-de-depoentes; https://oglobo.globo.com/brasil/conducaocoercitiva-de-lula-na-lava-jato-gera-polemica-no-meio-juridico-18811380. Acesso em: 12 nov. 2018.
} 
proteção da comunicação entre o advogado seu cliente, é prerrogativa ope legis, decorrente do estatuto da $\mathrm{OAB}$, e prerrogativa de meio de defesa do réu. A violação à esfera protetiva demonstrou-se de maneira tão evidente, que a própria Ordem dos Advogados do Brasil requereu ao Supremo Tribunal Federal que invalidasse o grampo, uma vez que chapado seu caráter ilícito. ${ }^{46}$

Foi assim que o judiciário deu à luz a uma condenação sem indícios de autoria e de materialidade ${ }^{47}$, condenando uma figura política por um crime de corrupção sem objeto, sem a prova das vantagens indevidas, com um magistrado que produziu uma sentença desligada do princípio da vinculação do juiz aos fatos da causa. Como já mencionado anteriormente, quando da explanação dos contornos do processo, a condenação restou baseada no conteúdo das informações prestadas em acordo de delação, não havendo qualquer comprovação documental, ou determinação de quando a vantagem ao réu foi concedida, sequer que vantagem foi essa.

É importante que se destaque o parecer do Procurador Geral da República oferecido nos autos da Reclamação Constitucional nº. 27.229/DF, trazido pela defesa de Lula em juntada:

"Somente após o juízo homologatório, no qual cabe ao juiz aferir o cumprimento da legalidade do acordo, em seus aspectos formais, há a apresentação de elementos de corroboração das informações anteriormente prestadas por parte do colaborador. Para fins de instrução do processo criminal, tais elementos é que, ordinariamente, interessam de fato, na medida em que as declarações dos colaboradores, isoladamente, não podem subsidiar a condenação do acusado - muito embora sejam suficientes para fundamentar a decisão de recebimento da denúncia.

1 Exemplificadamente:

há acordos de colaboração premiada firmados com José Adelmário Pinheiro Filho ou com Agenor Franklin Magalhães Medeiros. Eventuais tratativas preliminares não interessam à defesa de qualquer acusado - aí incluído o reclamante -, tanto porque, nesse momento, ainda não se tem certeza acerca do fornecimento de informações incriminadoras, quanto pela possibilidade de que essas tratativas subsidiem a realização de diligências investigativas, das quais o sigilo seja condição necessária de exequibilidade e eficácia.

[...]

As afirmações do reclamante de que 'o douto Magistrado adiou o conhecimento da informação e de diligência já documentadas ao Paciente, cerceando a ampla defesa mediante redução do tempo para se trabalhar com a informação [...]' consistem em

46 Disponível em: https://www.conjur.com.br/2017-nov-13/mpf-acesso-grampo-feito-escritorioadvogados-lula. Acesso em: 12 nov. 2018.

47 Disponível em: https://noticias.uol.com.br/politica/eleicoes/2018/noticias/2018/01/25/analiseato-de-corrupcao-de-lula-em-contratos-da-oas-nao-ficou-claro.htm. Acesso em: 12 nov. 2018. 
suposição despida de qualquer sentido. Não há nenhum elemento de prova obtido a partir dessas tratativas preliminares já documentado em qualquer procedimento investigativo que seja." 48

Assim, traz-se também o despacho dado pelo juízo da $13^{\mathrm{a}}$ Vara Federal de Curitiba, em sede de Embargos de Declaração em relação à sentença proferida:

"Este Juízo jamais afirmou, na sentença ou em lugar algum, que os valores obtidos pela Construtora OAS nos contratos com a Petrobrás foram utilizados para pagamento da vantagem indevida para o ex-Presidente."

É evidente a ausência de materialidade do crime praticado em tese, fato que restou explanado na sentença condenatória e no parecer do Procurador Geral da República. Contudo, mesmo assim, o processo cominou na condenação do réu, que se apresentou em juízo sem a chance de defesa justa, sem que houvesse oferta do direito ao contraditório ou ampla defesa, afinal, seu julgamento já havia sido realizado, porém não por um tribunal legitimado.

\subsection{Inquérito Policial - Escola Base}

É imprescindível para que se determine a importância do tema tratado, que seja realizado o estudo dos efeitos em um processo que não se valha de interesse público. Fala-se isso, uma vez que, mesmo que cientificado todas as arbitrariedades e desvios processuais no processo de Lula, ainda há de se pesar a matéria relativa ao bem público, que envolvia o objeto do processo.

É assim, que traçaremos os contornos do Trial by the mídia no caso que envolveu a Escola Base, em São Paulo.

No ano de 1992 Maria Aparecida Shimada e Icushiro Shimada (Ayres), Saulo e Mara Nunes, juntamente com o casal Paula Milhim Alvarenga e o seu esposo, e motorista da Kombi que transportava os alunos da escola, Maurício Monteiro de Alvarenga, compraram ${ }^{49}$ a escola. $\mathrm{Na}$

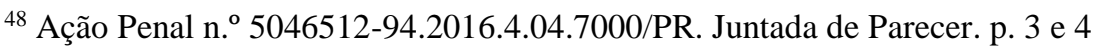

${ }^{49}$ Disponível em: http://www.justificando.com/2014/12/10/da-serie-julgamentos-historicos-escolabase-a-condenacao-que-nao-veio-pelo-judiciario/. Acesso em: 12 nov. 2018.
} 
época, contavam com apenas dezessete alunos, e às vésperas de fechar as portas, contudo, dentro de dois anos, a escola já contava com setenta e dois alunos, em plena ascendência.

O caso tem seu marco de início no ano de 1994, com o relato da mãe do aluno Fábio, então com quatro anos de idade, sobre seu comportamento. Isso porque, segundo relato da mesma, enquanto a criança brincava, sentouse em cima de sua barriga realizando movimentos e dizendo "o homem faz assim com a mulher" (RIBEIRO, 2000, p. 20) ${ }^{50}$. Ao inquiri-lo a respeito da origem de tal ação, a criança não respondeu.

$\mathrm{O}$ autor Alexandre Ribeiro, que escreveu sobre o caso em questão, narra:

"Lúcia voltou ao quarto. Ninguém presenciou a inquirição, mas o fato é que ela saiu de lá dizendo que o menino revelara barbaridades. A fita pornográfica, ele a teria visto na casa de Rodrigo, um coleguinha da Escola Base. Um lugar com porão verde, jardim na lateral, muitos quartos, cama redonda e aparelho de televisão no alto seria levado a essa casa por uma perua Kombi, dirigida por Shimada - o Ayres, marido da proprietária da escolinha. Fábio teria sido beijado na boca por uma mulher de traços orientais, e o beijo fotografado por três homens: José Fontana, Roberto Carlos e Saulo, pai do Rodrigo. Maurício - marido de Paula, sócia da escolinha - teria agredido o pequeno a tapas. Uma mulher de traços orientais faria com que ele virasse de bruços para passar mertiolate em suas nádegas. Ardia muito, foi o que o garoto disse à mãe. E uma mulher e um homem ficariam "colados" na frente dele. Outros coleguinhas teriam participado da orgia: Iracema, Rodrigo e Cibele. Lúcia conhecia a mãe de Cibele, Cléa Parente de Carvalho, e lhe contou sobre os relatos de Fábio. Desesperada, Cléa foi conversar com a filha, que teria lhe contado tudo, mas, da mesma forma como ocorreu com Lúcia e Fábio, ninguém presenciou a conversa. A menina teria contado horrores, coisas absurdas, dentre as quais "que teria sido introduzido em seu ânus um objeto esquisito, que ela não sabia descrever", que "assistia a filmes de mulheres peladas e era fotografada nua" e que "os tios ficavam sem roupas e deitavam em cima dela" (RIBEIRO, 2000, p. 23)."51

Diante do narrado, as mães cientificaram a autoridade sobre o fato, tendo a titularidade das investigações ficado a cargo do delegado Edélson Lemos, que procedeu ao encaminhamento das crianças ao IML, para realização de exames que pudessem comprovar a materialidade do crime. Ocorre que, o delegado, ao receber a notícia crime ligou para o editor do

\footnotetext{
${ }^{50}$ RIBEIRO, Alex. Caso Escola Base: Os abusos da imprensa. São Paulo: Editora Ática, 2003.

${ }^{51} \mathrm{Ibid}$
} 
jornal Diário, Paulo Breitenvieser, relatando o conteúdo dos relatos realizados.

É possível, no caso em análise, destacar a má-fé da autoridade no tratamento dos fatos em questão, segundo o autor Alex Ribeiro (2000, p. 34), de início o caso foi narrado como sendo uma boa história a respeito de abuso infantil envolvendo crianças de quatro anos de idade. Assim sendo, foi emitido mandado de busca e apreensão na Escola Base, não tendo nada sido encontrado, não restando qualquer indício de autoria e materialidade encontrados.

No mesmo dia em que os donos da Escola Base foram chamados a prestar informações de maneira informal, repórteres da Globo já aguardavam junto à delegacia na espera de Ayres, Aparecida, Paula e Maurício, que relatam ter sofrido violência física e psicológica durante o interrogatório, como narrado por (Ribeiro 2000).

O IML por sua vez, emitiu o laudo pericial do infante, no qual constava:

"referente ao laudo n'. 6.254/94 do menor F.J.T Chang, BO 1827/94, informamos que é positivo para a prática de atos libidinosos. Dra. Eliete Pacheco, setor de sexologia, IML, sede". 52

Tal informação foi o que desencadeou a massificação de reportagens a respeito do caso. A partir do laudo do IML, a cobertura passou a se dar de maneira integral, sendo relatado por todos os jornais. Fala-se isso em uma realidade tecnológica que não conhecia a internet. As informações que decorriam a respeito do fato viam de fontes midiáticas tradicionais, de renome e peso, não sendo veiculadas de maneira cartular apenas, como também televisionada pelas grandes emissoras.

Aqui a questão mais danosa se reflete no fato de que não havia possibilidade de auferir os fatos por meio de fontes alternativas de informação, que, apesar da parcialidade decorrente da conjuntura atual, se fazem presentes. O que se observou, foi uma completa usurpação da

\footnotetext{
${ }^{52}$ RIBEIRO, Alex. Caso Escola Base: Os abusos da imprensa. São Paulo: Editora Ática,
} 2003 , p. 41. 
competência investigativa do judiciário pelas mídias tradicionais que, a exemplo da edição do Jornal Nacional, no mesmo dia, transmitiam os fatos narrados pelas mães das crianças, sem se preocupar em noticiar que não havia sido realizada a colheita de prova, ou que não havia sido capaz de auferir qualquer indício de crime praticado pelos acusados.

A possibilidade dos envolvidos no suposto crime retomarem sua vida de maneira proba e sem sequelas relativas aos atos alegados na notícia crime, foi minada pela série de declarações dadas pelo delegado envolvido no caso à imprensa. $\mathrm{O}$ conteúdo do atestado pela autoridade insinuou a culpa dos sócios da escola no crime de pedofilia, bastando para que todos os veículos de informação os sentenciassem, por meio da divulgação de matérias sensacionalistas, de um fato que nunca ultrapassou a fase do inquérito policial.

Dentre as manchetes, elencavam-se "consumo de drogas" “contaminação pelo vírus da AIDS", "Perua carregava crianças para orgia", "Kombi era motel na escolinha do sexo". 53

A Escola Base, ao curso da campanha midiática, foi depredada, os donos da escola mudaram-se para fugir dos linchamentos e das ameaças recebidas. O relator da CPI da Prostituição Infanto-Juvenil pediu a quebra do sigilo bancário dos suspeitos, enquanto as manchetes estampavam os sofrimentos das mães diante dos abusos suportados pelas crianças.

O clamor para a resolução do caso foi tão intenso, que diante dos sucessivos erros cometidos pelo delegado na abordagem do caso, o mesmo foi transferido para outra delegacia, sob outra titularidade, o que não contribuiu para o reequilíbrio do processo. Isso porque o novo delegado sob titularidade do caso deflagrou um mandado de busca e apreensão no endereço errado, cominando na prisão do americano Richard Pedicini, morador do

\footnotetext{
${ }^{53}$ Disponível em: http://www.justificando.com/2014/12/10/da-serie-julgamentos-historicos-escolabase-a-condenacao-que-nao-veio-pelo-judiciario/. Acesso em: 12 nov. 2018.
} 
imóvel erroneamente tomado como local do crime, acusado falsamente pelo crime de abuso e pornografia infantil. ${ }^{54}$

Ao levar as crianças para o reconhecimento da casa, o fato de uma das crianças ter se predisposto a brincar com um objeto presente no imóvel foi o suficiente para que fosse considerado o reconhecimento do local. Restou-se comprovado depois que Richard sequer possuía conhecimento a respeito dos donos a escola.

A primeira entrevista conduzida de maneira imparcial em relação aos acusados, deu-se pela Rede Cultura, conduzida pelo jornalista Florestan Fernandes Jr. Assim sendo, deu-se início à fase de ponderação ao que estava sendo noticiado, o jornalista Luís Nassif, da TV Bandeirantes, pronunciouse da seguinte maneira, em prol dos acusados:

\begin{abstract}
Bom, hoje eu não vou falar de economia, vou falar de um assunto que me deixa doente. Toda a imprensa está há uma semana denunciando donos de escola que presumivelmente teriam cometido abuso sexual contra crianças de quatro anos. Toda a cobertura se funda em opinião da polícia. Está havendo um massacre. Mais que isso, está havendo um linchamento. Se eles forem culpados, não é mais que merecido. E se não forem? Uma leitura exaustiva de todos os jornais mostra o seguinte: não há até agora nenhuma prova conclusiva de que a criança foi violentada por adultos. Não há nenhuma prova conclusiva contra as pessoas que estão sendo acusadas. Tem-se apenas a opinião de policiais que ganharam notoriedade com denúncias e, se eventualmente se descobrir que as denúncias são falsas, vão ter muita dificuldade de admitir. Por isso, a melhor fonte não é a polícia, neste momento. A imprensa deve as pessoas que estão sendo massacradas, no mínimo, um direito de defesa, de procurar versões fora da polícia. Repito: é possível que as pessoas sejam culpadas. Mas é possível que sejam inocentes. E se forem inocentes? ? $^{55}$
\end{abstract}

Foi o início da retomada do discurso de ponderação, que deixou a inquisição de lado. A partir desse fato, novas provas da inocência dos acusados foram surgindo, aliado ao fato de que nenhuma prova da existência do crime, sequer da autoria dos donos da escola foi de fato encontrada.

$\mathrm{Na}$ esteira da investigação jornalística que buscava de fato compreender os fatos, o jornal Folha da Tarde entrevistou o presidente da Associação Paulista de Medicina, José Kanopolish, a respeito do laudo

\footnotetext{
${ }^{54}$ Disponível em: https://www1.folha.uol.com.br/fsp/1995/5/05/cotidiano/36.html. Acesso em: 12 nov. 2018

${ }^{55}$ RIBEIRO, Alex. Caso Escola Base: Os abusos da imprensa. São Paulo: Editora Ática, 2003. P. 99 e 100
} 
emitido pelo IML. Em seu parecer, não havia como de fato confirmar o abuso sexual, pois os indícios que foram encontrados, podiam decorrer igualmente de podia ser micose, vermes ou fezes duras (RIBEIRO, 2000)

Os erros cometidos pela autoridade policial foram tão significativos, que no intento de demonstrar que a prestação investigativa estava sendo efetivada, o delegado conduziu o interrogatório das crianças, sem que houvesse a presença de um psicólogo, fato criticado pela coordenadora do Serviço de Advocacia da Criança da OAB, Lia Junqueira (RIBEIRO, 2000, p. 101), em declaração publicada na Folha de São Paulo.

Então, Gérson de Carvalho, delegado titular das investigações, inocentou os acusados, não tendo todo o ocorrido ultrapassado da fase do inquérito policial, sem substância o suficiente para formar uma denúncia. As mídias iniciaram suas retratações, contudo, o dano já se encontrava consubstanciado, não havia mais o que fazer. ${ }^{56}$

Isso porque os donos perderam a escola e os funcionários perderam seus empregos, mudaram de casas e tiveram seu sustento e ofício exauridos, tanto pelas consequências das acusações como para o pagamento dos honorários dos advogados.

Ao todo os órgãos de imprensa Folha de São Paulo, Estado de São Paulo, Globo, SBT, Record, Rádio e TV Bandeirantes, ISTOÉ, Veja, Notícias Populares e Folha da Tarde, foram condenados ao pagamento de indenizações aos investigados. É necessário que se destaque que essas foram irrisórias diante do dano suportado pelos sócios, e da incapacidade posterior em retomar suas vidas.

As vítimas de fato do crime cometido pela tendenciosidade jornalística, sofrem até hoje com o ocorrido, todos possuem problemas financeiros, decorrente do esforço em retomar suas vidas. Maria Aparecida Shimada, morreu de câncer em 2007 e Ayres, seu esposo, morreu vítima de enfarto em 2014. Maurício Alvarenga foi diagnosticado com síndrome do

\footnotetext{
56 Disponível em: http://jornal.puc-campinas.edu.br/o-caso-escola-base-2/; https://www.pragmatismopolitico.com.br/2012/12/caso-escola-base-rede-globo-e-condenadapagar-r-135-milhao.html Acesso em: 12 nov. 2018.
} 
pânico, não conseguindo mais sair de casa sem que estivesse disfarçado.

Paula Alvarenga, desenvolveu um quadro de obesidade, seguida de depressão, nunca mais conseguindo emprego como professora, sua profissão por natureza. ${ }^{57}$ Saulo e Mara Nunes sofreram de problemas financeiros pelas dividas contraídas na contratação de advogados.

É assim que se traz o relatório do caso constante do acordão, apresentado em sede de Recurso Especial No 1.215.294 - SP (2010/0177517$0)$, que trata sobre uma das indenizações devidas pela empresa TVSBT CANAL 4 DE SÃO PAULO S/A:

"É de se duvidar que alguém, contemporâneo aos fatos relatados na presente demanda, tenha esquecido os abusos morais e físicos a que foram submetidos os autores, ora recorridos, que tiveram sua escola depredada e jamais poderão exercer novamente atividade semelhante. Não há como negar que, muitas vezes, a condenação imposta pela mídia suplanta a condenação judicial, embora nossa Constituição Federal defenda a liberdade de imprensa tanto quanto defende o princípio da proteção da honra e da intimidade da pessoa. Desse modo, o espetáculo midiático deve ser coibido pela eficácia dessas garantias. De fato, em 28 de março de 1994, toda a imprensa brasileira, incitada pelo delegado que cuidava do caso, divulgou uma série de matérias referentes a um suposto crime de abuso sexual praticado contra alunos da Escola Base, no bairro da Aclimação, na cidade de São Paulo. Duas mães de alunos dirigiram-se ao Distrito Policial, queixando-se que seus filhos, crianças de 4 anos de idade, haviam sido vítimas de abuso sexual. Os acusados eram os donos da escola, Icushiro Shimada e sua esposa Aparecida Shimada, bem como os sócios Paula e Maurício Alvarenga, e o casal de pais Saulo da Costa Nunes e Mara Cristina França. O que se viu, pelas matérias e notícias divulgadas, foi uma desenfreada credulidade nas "denúncias" feitas pelas mães e nos depoimentos de crianças de 4 anos, tomando-se por verdadeiro tudo que era dito. Manchetes sensacionalistas levavam aos leitores à revolta quando se referiam ao caso da "escolinha do sexo". Assim, antes mesmo do arquivamento do inquérito insuficientemente iniciado, porquanto as lesões encontradas poderiam ser atribuídas tanto à violência sexual como a problemas intestinais, os veículos da mídia, além de não manterem a devida parcialidade, acabaram por produzir matérias sensacionalistas que resultaram na execração pública dos donos e dos sócios da escola" ${ }^{" 58}$

O caso referente a escola base é representativo do total cerceamento proporcionado pela formação de um juízo inquisitório. Mais grave ainda, que não se reuniu sequer elementos suficientes para a formação de um processo, no entanto foi o necessário para manter cativas quaisquer prerrogativas que

\footnotetext{
${ }^{57}$ Disponível em: http://www.justificando.com/2014/12/10/da-serie-julgamentos-historicos-escolabase-a-condenacao-que-nao-veio-pelo-judiciario/. Acesso em: 12 nov. 2018.

${ }^{58}$ Disponível em: https://www.conjur.com.br/dl/escola-base-acordao-stj-sbt.pdf. Acesso em: 12 nov. 2018.
} 
os acusados possuíssem. Impedindo o mínimo resquício de presunção de inocência.

Fica claro, por meio do caso concreto, como a linha entre o direito a informação, diante da prerrogativa de manter informada a população, e o cerceamento de direitos fundamentais relativos à justiça e a liberdade do indivíduo mostra-se tênue. O cuidado demonstrado nos casos, pelos órgãos da justiça, e pela maneira que são conduzidas as diretrizes informativas, beiram ao desleixo.

É o que se pode perceber do caso produzido pela cobertura do inquérito relativo a escola base, que destroçou a esfera de direitos daqueles investigados, impossibilitando qualquer meio da manutenção de suas vidas após os fatos, mesmo tendo sido inocentados sem que houvesse sequer matéria processual. 


\section{Conclusão}

É imperativo que se compreenda a relevância da influência da coletividade no devido processo legal, e de como as mídias influenciam para o seu desfecho, seja ele no âmbito jurídico ou social. Isso justifica-se pelo entendimento de que o cerceamento de defesa e da presunção de inocência frente ao poder punitivo a que detém o Estado configura cisão da liberdade sem a devida justificativa.

As implicações desse entendimento encontram respaldo no fato de que, sem a garantia de uma justiça proba, integra e imparcial, não há que se falar em fé pública ou garantia de segurança jurídica, sendo tais características inerentes da construção democrática. O que se está a por em xeque, posto isso, é o próprio sentido do processo, que se perde diante de uma condenação despida de parâmetros legais.

Tal prerrogativa faz-se ainda mais necessária em um país que ainda encontra dificuldades de fazer valer direitos básicos de uma Constituição promulgada há 30 anos. A Carta Cidadã, de forma alguma, pode encontrar sua finalidade no fato de resumir-se em uma carta de intenções, âmbito no qual o Judiciário ganha especial relevância, uma vez que possui como prerrogativa a legitimidade para agir na garantia da efetivação de tais direitos.

Nesse diapasão, o estudo das prerrogativas e garantias constitucionais do processo, e os meios pelo qual essas restam cerceadas por mecanismos extrajurídicos é de fundamental relevância para que se entenda a insipida proteção que resguardam frente à novas tecnologias de informação.

Isso-justifica-se pelo fato de que, apesar do direito ser ciência que acompanha o progresso social, não deve fechar os olhos para a dinamicidade tecnológica que exerce cada vez mais influência sobre direitos fundamentais de natureza indisponível.

A influência que a formação de tribunais e juízes deslegitimados por meio de denúncias e sentenças produzidas por matérias jornalísticas não pode ser subestimada. Não se postula a limitação do exercício da imprensa, pelo 
contrário, uma vez que de sua liberdade decorre a efetivação e consolidação de bases democráticas, mas a imprescindível atuação na fiscalização da relevante função que exerce.

Contudo, como defendido, todos os direitos para que sejam de fato efetivados devem munir-se de ponderação em seu exercício, já que quando empreendidos de maneira absoluta acabam por suprimir o outro.

O desafio que se apresenta é um desafio que concerne a um Estado que ainda engatinha na garantia dos fundamentos que o constituem. Posto isso, a linha entre o limite do exercício de determinada garantia e sua limitação, deve restar traçada e determinada. Apenas dessa maneira, é possível que se consubstancie um Estado que de fato se caracterize por sua natureza democrática. 


\section{Bibliografia}

Artigo 179 da Constituição do Império 1824. Disponível em http://www.planalto.gov.br/ccivil_03/constituicao/constituicao24.htm4

Primeira Constituição da República. Disponível em http://www.planalto.gov.br/ccivil_03/Constituicao/Constituicao91.htm

Texto da Constituição de 1934 disponível em: http://www.planalto.gov.br/ccivil_03/Constituicao/Constituicao34.htm

Texto da Constituição de 1937 disponível em: http://www.planalto.gov.br/ccivil_03/Constituicao/Constituicao37.htm. Acesso em: 20 out. 2018.

Texto da Constituição de 1946. Disponível em: http://www.planalto.gov.br/ccivil_03/Constituicao/Constituicao46.htm. Acesso em: 20 out. 2018.

Texto da Constituição de 1967 disponível em: http://www.planalto.gov.br/ccivil_03/Constituicao/Constituicao67.htm. Acesso em: 20 out. 2018.

Ação Penal n. o 5046512-94.2016.4.04.7000/PR. Juntada de Parecer. p. 3 e 4 BARROSO, Luís Roberto. Curso de Direito Constitucional Contemporâneo. Editora Saraiva

BASTOS, Márcio Thomaz. Júri e Mídia. Tribunal do Júri: Estudo sobre a mais democrática instituição jurídica brasileira. São Paulo: Revista dos Tribunais, 1999.

CERDA, Juliana Andrade. Análise Crítica acerca da Influência da Mídia no Processo Criminal Brasileiro. Escola da Magistratura do Estado do Rio de Janeiro.

Declaração Universal dos direitos do homem e do cidadão

Declaração Universal dos direitos do homem, disponível no site da UNICEF

Denúncia do Ministério Público Federal. Procuradoria da República do Paraná. Distribuição por dependência aos autos $\mathrm{n}^{\circ}$ 500661729.2016.4.04.7000/PR e 5035204-61.2016.4.04.7000/PR

GRECO, Rogério. Curso de Direito Penal - Parte Geral. Editora Impetus.

Jornal Folha de São Paulo. Tendências/debates. Dignidade sob pressão. 06 de Novembro de 2018.

LACERDA, Juliana Andrade. Análise Crítica acerca da Influência da Mídia no Processo Criminal Brasileiro. Escola da Magistratura do Estado do Rio de Janeiro 
MENDES, Gilmar Ferreira e BRANCO, Paulo Gustavo Gonet. Curso de direito Constitucional. Editora Saraiva

MORETZSOHN, Sylvia. Jornalismo em Tempo Real: O Fetiche da Velocidade. Rio de Janeiro: Revan, 2002, p. 70.

NADER, Paulo. Introdução ao Estudo do Direito. 23ª Ed. Rio de Janeiro: Forense, 2003.

RIBEIRO, Alex. Caso Escola Base: os abusos da imprensa. São Paulo: Editora Ática, 2003.

SAMPAIO JUNIOR, José Herval. Processo Constitucional: nova concepção de jurisdição. São Paulo: Método, 2008.

SCHREIBER, Simone. A Publicidade Opressiva de Julgamentos Criminais. Rio de Janeiro: Renovar, 2008.

SILVA, José Afonso da. Constituição e segurança jurídica, in ROCHA, Carmen Lúcia Antunes. Constituição e segurança jurídica.

TÁVORA, Nestor e ALENCAR, Rosmar Rodrigues. Curso de Direito Processual Penal. Editora JusPodivm.

\section{Sites}

Disponível

em: https://economia.uol.com.br/cotacoes/noticias/redacao/2018/01/23/mercado -ve-julgamento-de-lula-como-divisor-de-aguas-para-o-futuro-do-pais.htm; Acesso em: 12 nov. 2018. Disponível em: https://oglobo.globo.com/economia/apos-condenacao-de-lula-dolar-fechaem-316-bolsa-salta-37-batendo-recorde-22321974. Acesso em: 12 nov. 2018 .

Disponível em: http://agenciabrasil.ebc.com.br/politica/noticia/201603/conducao-coercitiva-de-lula-provoca-debate-sobre-coercao-dedepoentes; https://oglobo.globo.com/brasil/conducao-coercitiva-de-lula-nalava-jato-gera-polemica-no-meio-juridico-18811380. Acesso em: 12 nov. 2018.

Disponível em: http://jornal.puc-campinas.edu.br/o-caso-escola-base-2/; https://www.pragmatismopolitico.com.br/2012/12/caso-escola-base-redeglobo-e-condenada-pagar-r-135-milhao.html Acesso em: 12 nov. 2018.

Disponível em: http://www.justificando.com/2014/12/10/da-seriejulgamentos-historicos-escola-base-a-condenacao-que-nao-veio-pelojudiciario/. Acesso em: 12 nov. 2018. 
Disponível em: http://www.justificando.com/2014/12/10/da-seriejulgamentos-historicos-escola-base-a-condenacao-que-nao-veio-pelojudiciario/. Acesso em: 12 nov. 2018.

Disponível em: http://www.justificando.com/2014/12/10/da-seriejulgamentos-historicos-escola-base-a-condenacao-que-nao-veio-pelojudiciario/. Acesso em: 12 nov. 2018.

Disponível

em: http://www2.stf.jus.br/portalStfInternacional/cms/destaquesNewsletter.php? sigla=newsletterPortalInternacionalNoticias\&idConteudo=214544. Acesso em: 12 nov. 2018.

Disponível

em: https://acervo.oglobo.globo.com/busca/?tipoConteudo=pagina\&pagina $=\& o$ rdenacaoData $=$ relevancia\&allwords $=$ Lula + lava + jato \&anyword $=\&$ noword $=$ \&exactword $=\&$ decadaSelecionada $=\&$ anoSelecionado $=\&$ mesSelecionado $=$ $\&$ diaSelecionado=. Acesso em: 12 nov. 2018.

Disponível em: https://exame.abril.com.br/brasil/a-linha-do-tempo-do-casotriplex-que-levou-lula-a-prisao/. Acesso em: 12 nov. 2018.

Disponível em: https://g1.globo.com/economia/noticia/cotacao-do-dolar060318.ghtml;

Disponível

em:

https://noticias.uol.com.br/politica/eleicoes/2018/noticias/2018/01/25/analis e-ato-de-corrupcao-de-lula-em-contratos-da-oas-nao-ficou-claro.htm.

Acesso em: 12 nov. 2018.

Disponível em: https://politica.estadao.com.br/blogs/faustomacedo/delacao-de-leo-pinheiro-vai-de-palestras-de-lula-a-doacoes-parainstituto/. Acesso em: 12 nov. 2018.

Disponível em: https://politica.estadao.com.br/blogs/faustomacedo/delacao-de-leo-pinheiro-vai-de-palestras-de-lula-a-doacoes-parainstituto/. Acesso em: 12 nov. 2018.

Disponível em: https://politica.estadao.com.br/blogs/fausto-macedo/exdiretor-da-oas-afirma-que-triplex-estava-reservado-a-lula/ Acesso em: 12 nov. 2018. Disponível em: https://g1.globo.com/politica/operacao-lavajato/noticia/perguntas-e-respostas-sobre-a-condenacao-de-lula-no-caso-dotriplex.ghtml. Acesso em: 12 nov. 2018.

Disponível em: https://politica.estadao.com.br/blogs/faustomacedo/delacao-de-leo-pinheiro-vai-de-palestras-de-lula-a-doacoes-parainstituto/. Acesso em: 12 nov. 2018.

Disponível em: https://www.brasil247.com/pt/247/brasil/334027/Erros-noprocesso-deveriam-anular-condena\%C3\% A7\% C3\% A3o-de-Lula-apontamjuristas.htm. Acesso em: 12 nov. 2018.

Disponível em: https://www.conjur.com.br/2017-nov-13/mpf-acessogrampo-feito-escritorio-advogados-lula. Acesso em: 12 nov. 2018. 
Disponível em: https://www.conjur.com.br/dl/escola-base-acordao-stjsbt.pdf. Acesso em: 12 nov. 2018.

Disponível em: https://www.valor.com.br/financas/5367047/dolar-temmaior-queda-em-3-semanas-com-julgamento-do-lula-e-exterior. Acesso em: 12 nov. 2018.

Disponível em: https://www.conjur.com.br/2009-jun-07/juizes-conviverpressao-critica-meios-comunicacao. Acesso em: 19 out. 2018.

Disponível em:

https://www1.folha.uol.com.br/fsp/1995/5/05/cotidiano/36.html. Acesso em: 12 nov. 2018. 